\title{
Spatial and seasonal variations of organic carbon distributions in typical intertidal sediments of China
}

\author{
Yushuang Zhang a,b ${ }^{\mathrm{a}}$ Xiaotong Xiao ${ }^{\mathrm{a}, \mathrm{b}, *}$, Dongyan Liu ${ }^{\mathrm{c}}$, Enhui Wang ${ }^{\mathrm{d}}$, Ke Liu ${ }^{\mathrm{a}, \mathrm{b}}$, Yang Ding ${ }^{\mathrm{a}, \mathrm{b}}$, Peng Yao ${ }^{\mathrm{a}, \mathrm{b}}$, \\ Meixun Zhao ${ }^{\mathrm{a}, \mathrm{b}, *}$ \\ ${ }^{a}$ Key Laboratory of Marine Chemistry Theory and Technology, Ministry of Education/Institute for Advanced Ocean Study, Ocean University of China, Qingdao 266100, China \\ ${ }^{\mathrm{b}}$ Laboratory for Marine Ecology and Environmental Science, Qingdao National Laboratory for Marine Science and Technology, Qingdao 266237, China \\ 'State Key Laboratory of Estuarine and Coastal Research, Institute of Eco-Chongming, East China Normal University, 500 Dongchuan Road, Shanghai 200241, China \\ ${ }^{\mathrm{d}}$ Key Laboratory of Coastal Environmental Processes and Ecological Remediation, Yantai Institute of Coastal Zone Research, Chinese Academy of Sciences, Yantai 264003, China
}

\section{A R T I C L E I N F O}

\section{Article history:}

Received 28 August 2019

Received in revised form 20 January 2020

Accepted 19 February 2020

Available online 20 February 2020

\section{Keywords:}

Chinese intertidal sediments

Biomarkers

Terrestrial OC

Marine OC

Carbon stock

\begin{abstract}
A B S T R A C T
Intertidal zones are the main sites for land-ocean interaction and play an important role in transporting and accumulating organic carbon $(\mathrm{OC})$. Understanding sources and preservation of sedimentary OC are vital to better evaluate the processes controlling the OC distribution in intertidal zones. In this study, we present bulk parameters of total organic carbon (TOC), $\delta^{13} \mathrm{C}_{\mathrm{org}}$, grain size and biomarker contents in surface sediments of 14 typical intertidal zones along China's coastline during both the wet season (WS) and the dry season (DS). Statistical analysis of our data set showed that TOC and biomarker contents were generally high in small estuaries, intermediate but more variable in large estuaries and low in nonestuaries; and these distribution patterns broadly correlated with sedimentary clay contents. TOC and biomarker contents were generally higher in the WS than the DS reflecting both OC inputs and preservation. A binary mixing model based on $\delta^{13} C_{\text {org }}$ and biomarker proxies revealed that large estuaries were characterized by higher terrestrial OC fractions (62-80\%) except for the Yellow River Estuary (24\%), while lower terrestrial OC fractions occurred in non-estuaries (13-15\%). Variable OC contributions were found in small estuaries, with most sites characterized by low terrestrial OC contributions (3-35\%), but high terrestrial OC contributions were found at the Qiantang River Estuary site (59\%) and the Jiulong River Estuary site (67\%). Carbon stocks in Chinese intertidal sediments are comparable with those in marine sediments from shelf areas and the Exclusive Economic Zone (EEZ). This study suggests that intertidal sediments are potentially an important carbon sink.
\end{abstract}

(c) 2020 Elsevier Ltd. All rights reserved.

\section{Introduction}

Intertidal sediments along the coastline receive detritus from both the land and the sea, and thus can trap and bury considerable quantities of natural and anthropogenic organic matter under the interactions of chemical, physical and biological processes (Fulton et al., 2004; Gonzalez-Macias et al., 2006; Qiao et al., 2007; Pote et al., 2008; Witt et al., 2010). The accumulation of organic matter is important for benthic communities (Cividanes et al., 2002; Wu et al., 2018), which attracts birds from far distant breeding grounds, and serves as a nursery for crabs, shrimp and fish (Reise, 1985). In the ocean, over half of the blue carbon is captured by coastal

\footnotetext{
* Corresponding authors at: Key Laboratory of Marine Chemistry Theory and Technology, Ministry of Education/Institute for Advanced Ocean Study, Ocean University of China, Qingdao 266100, China.

E-mail addresses: xtxiao@ouc.edu.cn (X. Xiao), maxzhao@ouc.edu.cn (M. Zhao).
}

ecosystems (Nellemann et al., 2009); for example, the averaged carbon sequestration of mangrove areas is about $226 \mathrm{~g} \mathrm{C} \mathrm{m}^{-2} \mathrm{yr}^{-1}$, while that of saltmarsh is about $218 \mathrm{~g} \mathrm{C} \mathrm{m}^{-2} \mathrm{yr}^{-1}$. Recently, a Carbon Storage (CS) index has been proposed to estimate the ability of wetlands to act as a carbon sink as one goal of the Ocean Health Index (OHI) (Halpern et al., 2012). In contrast, there is limited information about carbon burial in intertidal sedimentary ecosystems, despite their importance in the ocean carbon cycle. Some studies have shown that the carbon sequestration of microphytobenthos growing on intertidal sediments can range from 29 to $476 \mathrm{~g} \mathrm{C}$ $\mathrm{m}^{-2} \mathrm{yr}^{-1}$, which is much higher than the carbon burial in temperate forests and grassland (Nellemann et al., 2009; Park et al., 2014). These studies have improved our knowledge of the marine OC cycle, but the controlling mechanisms of OC burial in intertidal sediments are far more complicated than those in shelf and open ocean sediments, as intertidal zones are strongly influenced by tidal forces, 
bioturbation and sediment mobilization. In addition, the relative fractions of OC from different origins are still largely unknown.

The composition of $\mathrm{OC}$ in intertidal zones is the result of the dynamic equilibrium between external inputs (e.g., oceans, rivers, land input and materials produced by human activity), autochthonous production and heterotrophic utilization (Marchand et al., 2003; Wang et al., 2003). Organic geochemical proxies have been used to study $O C$ sources, transport and deposition processes (Hensen et al., 2000; Killops and Killops, 2005). For example, total OC (TOC) contents and stable carbon isotope ratios $\left(\delta^{13} C_{\text {org }}\right)$ have been used to reveal the amount and the sources (terrestrial or marine origin) of sedimentary OC, respectively. Biomarkers, however, have specific origins and can be used to distinguish terrestrial and marine OC (c.f. Pancost and Boot, 2004; Kim et al., 2006; Weijers et al., 2009; Smith et al., 2012). Long-chain $n$-alkanes from higher land plant leaf waxes, can serve as indicators for terrestrial OC input to marine sediments (Eglinton and Eglinton, 2008). Sterols, such as brassicasterol/epi-brassicasterol and dinosterol have been used to indicate OC produced by diatoms and dinoflagellates, respectively (Volkman et al., 1998; Volkman, 2003, 2006). Branched glycerol dialkyl glycerol tetraethers (brGDGTs) are mainly produced by anaerobic bacteria in soils (Hopmans et al., 2004; Weijers et al., 2006a) and have been used to trace terrestrial OC and, more specifically, as a proxy for soil OC in marine sediments (Hopmans et al., 2004; Weijers et al., 2009). Isoprenoid GDGTs (iGDGTs), of which crenarchaeol is a main component, are produced by marine planktonic archaea (Sinninghe Damsté et al., 2002), though small amounts of crenarchaeol have also been detected in soil (Schouten et al., 2000; Powers et al., 2004, 2010; Weijers et al., 2006b).

In the past two decades, a few organic geochemical studies have been carried out in intertidal zones. For example, in the Wadden Sea of Germany, the origin and composition of organic matter in intertidal sediments were analyzed, indicating that the variations in organic matter quantity, composition and quality were affected by the depositional environment and microbial transformation during early diagenesis (Freese et al., 2008). Along the European Atlantic coast, Middelburg and Herman (2007) investigated the intertidal estuaries, showing that riverine organic matter was extensively modified in intertidal estuaries before its transfer to the sea. In the Huon Estuary of Australia, the sources of organic matter in sediments were dominated by terrestrial input, which were probably refractory and slowly remineralized (Cook et al., 2004). China's long and wide intertidal zones cover an area of $2.17 \times 10^{4} \mathrm{~km}^{2}$, which is equivalent to $2.26 \%$ of China's mainland. In recent years, the source and preservation of organic matter in sediments of intertidal zones in China have also been investigated, such as in the wetland of the Liao River Delta (Lin et al., 2013), along the coast of Jiangsu Province (Liu et al., 2007), in the intertidal sediments from the Yangtze Estuary (Liu et al., 2006; Yang et al., 2008), and in the saltmarsh of Hangzhou Bay (Yuan et al., 2017). However, there are no reports focusing on comprehensive comparisons of the OC distribution and origin in sediments among different intertidal zones of China's coastal area, or of the mechanisms controlling OC burial.

Here, we present bulk parameters (TOC, $\delta^{13} \mathrm{C}_{\mathrm{org}}$, and grain size), plus terrestrial and marine biomarkers distributions, in surface sediments at 14 sites from different intertidal zones along China's coastline during both the wet season (WS) and the dry season (DS). To quantitatively distinguish the contributions of marine and terrestrial $\mathrm{OC}$, we used binary mixing models based on $\delta^{13} C_{\mathrm{org}}$, the terrestrial and marine biomarker ratio (TMBR) and the branched isoprenoid tetraether index (BIT). We calculated carbon stocks of intertidal sediments to assess potential implications for the management of differently sourced OC on coastal environments. Our study provides important insights for understanding the spatial and seasonal variations of sedimentary OC distributions in China's intertidal zones and its relation to the oceanic OC cycle.

\section{Material and methods}

\subsection{Sampling locations and materials}

28 surface sediments ( $\sim 2 \mathrm{~cm}$ depth) were collected during autumn or winter in 2014 (DS) and summer in 2015 (WS) at 14 sites along the coastal intertidal zones of China, consisting of small estuaries (discharges $<50$ billion $\mathrm{m}^{3} / \mathrm{a}$ ), large estuaries (discharges $>50$ billion $\mathrm{m}^{3} / \mathrm{a}$ ), and non-estuarine areas (Fig. 1; Table 1). The quantity of sediments at site 6 in the Dagu River Estuary during DS was only enough for bulk measurements, but not sufficient for biomarker analysis.

\subsection{Sediment grain size}

Sediment grain size was measured using a laser Particle Size Analyzer (Mastersizer 2000, Malven Instruments Ltd., UK) following the method of Hu et al. (2009). Particle sizes were separated into the following three groups: clay $(<4 \mu \mathrm{m})$, silt $(4-63 \mu \mathrm{m})$, and sand $(>63 \mu \mathrm{m})$. The relative error of the duplicate samples was less than $3 \%(n=6)$.

\subsection{TOC and $\delta^{13} C_{\text {org }}$ analysis}

About $1 \mathrm{~g}$ of each sediment was freeze-dried and homogenized, and then $4 \mathrm{~N} \mathrm{HCl}$ was added to remove carbonate. After rinsing with Milli-Q water until neutral, the sediments were dried in an oven at $55^{\circ} \mathrm{C}$. The carbonate-free samples were measured for TOC in duplicate using a Thermo Scientific Flash 2000 elemental analyzer, with a standard deviation of $0.02 \mathrm{wt} \%(n=6) \cdot \delta^{13} \mathrm{C}_{\text {org }}$ was determined on carbonate-free sediments that had been pretreated as described above using an isotope mass spectrometer (Thermo Scientific Delta V Advantage). The standard deviation was less than $\pm 0.2 \%$ o $(n=6)$, determined by six runs of IAEA-600, an inter-laboratory comparison standard distributed by the International Atomic Energy Agency (IAEA), Vienna. $\delta^{13} \mathrm{C}_{\text {org }}$ values are reported in the $\delta$ notation relative to international standard V-PDB (Vienna Pee Dee Belemnite) in units of parts per mil (\%o) and calculated as follows:

$\delta^{13} \mathrm{C}_{\text {org }}(\%)=\left[\mathrm{R}_{\text {sample }} / \mathrm{R}_{\text {standard }}-1\right] \times 1000$

where $R_{\text {sample }}$ and $R_{\text {standard }}$ are the isotopic ${ }^{13} \mathrm{C} /{ }^{12} \mathrm{C}$ ratios of the samples and standards, respectively.

\subsection{Biomarker analysis}

Biomarker extraction and purification follow the procedure of Zhao et al. (2006). About $5 \mathrm{~g}$ of each freeze-dried sediment was extracted with dichloromethane:methanol (DCM/MeOH) $(3: 1, \mathrm{v} /$ v) using sonication, after adding internal standards $C_{19} n$-alkanol, $n-C_{24} D_{50}$ and $C_{46}$ GDGT. The extracts were first hydrolyzed with $\mathrm{KOH}$ in $\mathrm{MeOH}(6 \%)$ for $12 \mathrm{~h}$ and then extracted with hexane. The extracts were subsequently separated into fractions using silica gel chromatography. The hydrocarbon fraction (containing $n$-alkanes) was eluted with $8 \mathrm{ml}$ of hexane. The polar lipid fraction was eluted with $12 \mathrm{ml}$ dichloromethane/methanol (95:5, v/v), and divided into two aliquots. The aliquot for sterol measurements was derivatized using $\mathrm{N}, \mathrm{O}-b i s($ trimethylsilyl)trifluoroacetamide (BSTFA) at $70^{\circ} \mathrm{C}$ for $1 \mathrm{~h}$ just prior to instrumental analysis. The other aliquot was filtered using a PTFE $0.45 \mu \mathrm{m}$ filter for GDGTs measurement. 


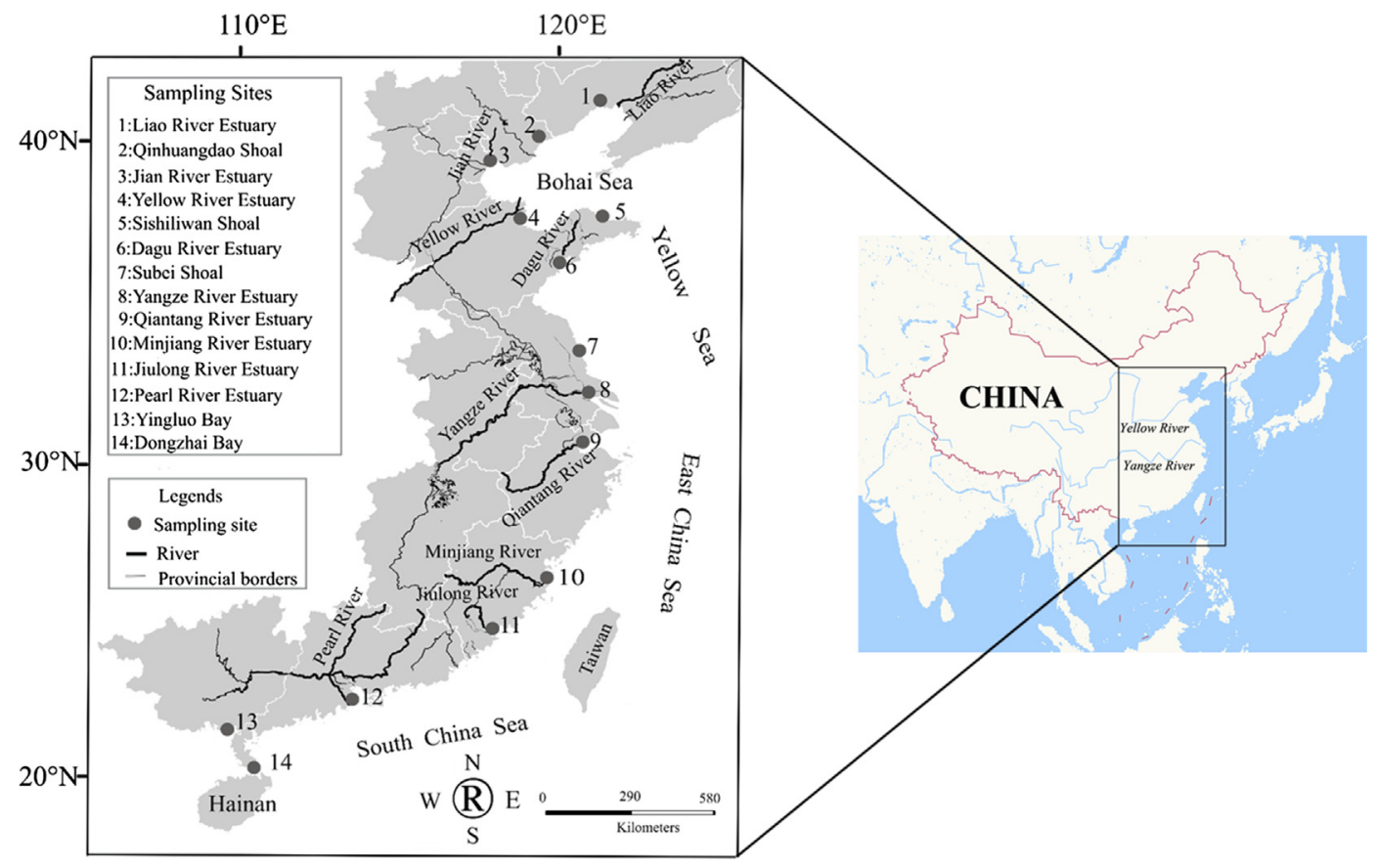

Fig. 1. Locations of the 14 intertidal sampling sites along China's coastline (black dots). Black lines indicate the rivers and gray shades indicate the watersheds.

Table 1

Sample information for the intertidal sediments.

\begin{tabular}{|c|c|c|c|c|c|c|}
\hline \multirow[t]{2}{*}{ Area Type } & \multirow[t]{2}{*}{ Sampling Site } & \multirow{2}{*}{$\begin{array}{l}\text { Longitude } \\
\left({ }^{\circ} \mathrm{E}\right)\end{array}$} & \multirow{2}{*}{$\begin{array}{l}\text { Latitude } \\
\left({ }^{\circ} \mathrm{N}\right)\end{array}$} & \multicolumn{2}{|c|}{ Date (month/year) } & \multirow[t]{2}{*}{ Typical vegetation types } \\
\hline & & & & $\begin{array}{l}\text { Dry } \\
\text { Season }\end{array}$ & $\begin{array}{l}\text { Wet } \\
\text { Season }\end{array}$ & \\
\hline \multirow[t]{5}{*}{$\begin{array}{l}\text { Small estuaries (river discharges }<50 \\
\text { billion } \mathrm{m}^{3} / \mathrm{a} \text { ) }\end{array}$} & $\begin{array}{l}1: \text { Liao River } \\
\text { Estuary }\end{array}$ & 122.13 & 40.61 & 9/2014 & $8 / 2015$ & Phragmites australis, Suaeda glauca Bunge \\
\hline & 3:Jian River Estuary & 117.96 & 39.21 & $9 / 2014$ & $8 / 2015$ & $\begin{array}{l}\text { Phragmites australis, Suaeda glauca Bunge, Aeluropus } \\
\text { sinensis Tzvel }\end{array}$ \\
\hline & $\begin{array}{l}\text { 6:Dagu River } \\
\text { Estuary }\end{array}$ & 120.19 & 36.20 & $10 / 2014$ & $7 / 2015$ & $\begin{array}{l}\text { Salicornia europaea, Suaeda glauca Bunge, Spartina } \\
\text { alterniflora Loisel }\end{array}$ \\
\hline & $\begin{array}{l}\text { 9:Qiantang River } \\
\text { Estuary }\end{array}$ & 121.46 & 30.29 & $2 / 2015$ & $8 / 2015$ & Spartina alterniflora Loisel, Phragmites australis \\
\hline & $\begin{array}{l}11 \text { :Jiulong River } \\
\text { Estuary }\end{array}$ & 117.95 & 24.41 & $12 / 2014$ & $7 / 2015$ & Spartina alterniflora Loisel, Mangrove \\
\hline \multirow[t]{4}{*}{$\begin{array}{l}\text { Large estuaries (river discharges }>50 \\
\quad \text { billion } \mathrm{m}^{3} / \mathrm{a} \text { ) }\end{array}$} & $\begin{array}{l}\text { 4:Yellow River } \\
\text { Estuary }\end{array}$ & 118.96 & 37.37 & $9 / 2014$ & $7 / 2015$ & $\begin{array}{l}\text { Spartina alterniflora Loisel, Phragmites australis, } \\
\text { Suaeda glauca Bunge }\end{array}$ \\
\hline & $\begin{array}{l}\text { 8:Yangtze River } \\
\text { Estuary }\end{array}$ & 121.97 & 31.47 & $2 / 2015$ & $7 / 2015$ & Spartina alterniflora Loisel, Phragmites australis \\
\hline & $\begin{array}{l}\text { 10:MinjiangRiver } \\
\text { Estuary }\end{array}$ & 119.64 & 26.04 & $12 / 2014$ & $7 / 2015$ & Spartina alterniflora Loisel, Phragmites australis \\
\hline & $\begin{array}{l}\text { 12:Pearl River } \\
\text { Estuary }\end{array}$ & 113.66 & 22.43 & $11 / 2014$ & $8 / 2015$ & Mangrove \\
\hline \multirow[t]{5}{*}{ Non-estuaries } & $\begin{array}{l}\text { 2:Qinhuangdao } \\
\text { Shoal }\end{array}$ & 119.52 & 39.85 & 9/2014 & $8 / 2015$ & - \\
\hline & 5:Sishiliwan Shoal & 121.45 & 37.38 & $10 / 2014$ & $7 / 2015$ & - \\
\hline & 7:Subei Shoal & 120.79 & 33.27 & $10 / 2014$ & $9 / 2015$ & $\begin{array}{l}\text { Spartina alterniflora Loisel, Phragmites australis, } \\
\text { Suaeda glauca Bunge }\end{array}$ \\
\hline & 13:Yingluo Bay & 109.76 & 21.47 & $11 / 2014$ & $9 / 2015$ & Mangrove \\
\hline & 14:Dongzhai Bay & 110.60 & 20.00 & $11 / 2014$ & $8 / 2015$ & Mangrove \\
\hline
\end{tabular}

$n$-Alkane and sterol quantifications were performed on an Agilent $6890 \mathrm{~N}$ GC with an FID detector, using a HP-1 capillary column ( $50 \mathrm{~m} \times 0.32 \mathrm{~mm}$ i.d., $0.17 \mu \mathrm{m}$ film thickness, J\&W Scientific) and $\mathrm{H}_{2}$ as the carrier gas at $1.3 \mathrm{ml} / \mathrm{min}$. For $n$-alkanes, the oven was kept initially at $80^{\circ} \mathrm{C}$ for $1 \mathrm{~min}$ and then programmed to $200^{\circ} \mathrm{C}$ at $25^{\circ} \mathrm{C} / \mathrm{min}$, followed by $4{ }^{\circ} \mathrm{C} / \mathrm{min}$ to $250^{\circ} \mathrm{C}, 1.7^{\circ} \mathrm{C} / \mathrm{min}$ to $300^{\circ} \mathrm{C}$ for $5 \mathrm{~min}$, and finally $5^{\circ} \mathrm{C} / \mathrm{min}$ to $310^{\circ} \mathrm{C}$ holding for $5 \mathrm{~min}$. For sterols, the oven was kept initially at $80^{\circ} \mathrm{C}$ for $1 \mathrm{~min}$ and then programmed to $200{ }^{\circ} \mathrm{C}$ at $25^{\circ} \mathrm{C} / \mathrm{min}$, followed by $4{ }^{\circ} \mathrm{C} / \mathrm{min}$ to $250{ }^{\circ} \mathrm{C}$, $1.7^{\circ} \mathrm{C} / \mathrm{min}$ to $300^{\circ} \mathrm{C}$ for $12 \mathrm{~min}$, and finally $5^{\circ} \mathrm{C} / \mathrm{min}$ to $320^{\circ} \mathrm{C}$ holding for $5 \mathrm{~min}$. The contents of alkanes and sterols were calculated from the ratio of their GC peak integrations to those of the $n$ $\mathrm{C}_{24} \mathrm{D}_{50}$ and $\mathrm{C}_{19} n$-alkanol internal standard, respectively (Zhao et al., 2006).

GDGTs were analyzed with an Agilent 1200 high performance liquid chromatograph (HPLC) coupled to a triple quadrupole mass spectrometer (Waters-Quattro Ultima Pt) equipped with an atmospheric pressure chemical ionization (APCI) probe. GDGTs were eluted at a flow rate of $0.2 \mathrm{ml} / \mathrm{min}$ with hexane/isopropanol for the first $5 \mathrm{~min}$, then with a linear gradient up to $1.8 \%$ isopropanol 
in $45 \mathrm{~min}$ in normal phase with a Prevail Cyano column $(150 \times 2.1 \mathrm{~mm}, 3 \mu \mathrm{m})$.

The MS instrument was operated under the conditions of nebulizer 60 psi, vaporizer $400{ }^{\circ} \mathrm{C}$, cone gas flow $\left(\mathrm{N}_{2}\right) 90 \mathrm{~L} / \mathrm{h}$ and desolvation gas flow $600 \mathrm{~L} / \mathrm{h}$, APCI source $95^{\circ} \mathrm{C}$, APCI probe $550^{\circ} \mathrm{C}$. Single ion monitoring (SIM) was used because of its increased reproducibility and lower signal/noise ratio (Schouten et al., 2007). SIM was set to scan $[\mathrm{M}+\mathrm{H}]^{+}$of crenarchaeol $(\mathrm{m} / \mathrm{z} 1292)$ and the brGDGTs (Ia + IIa + IIIa) (m/z 1050, 1036 and 1022), with a dwell time of $100 \mathrm{~ms}$ each. The relative abundances of GDGTs were obtained by comparing each respective $[\mathrm{M}+\mathrm{H}]^{+}$peak area with that of the internal standard ( $m / z$ 744) (Huguet et al., 2006). The average relative standard deviation was $<10 \%$. The biomarker contents are reported as ng/g of bulk dry weight sediment.

\subsection{The proxy indices}

TMBR is a proxy based on the ratio between terrestrial biomarkers and phytoplankton biomarkers, proposed by (Xing et al., 2011):

TMBR $=$ Long-chain $\sum n$-alkanes $/\left(\right.$ long-chain $\sum n$-alkanes $\left.+\sum \mathrm{PB}\right)$

where $\sum$ PB (sum of phytoplankton biomarkers) is the sum of $C_{37}$ alkenones, brassicasterol/epi-brassicasterol and dinosterol. Since $\mathrm{C}_{37}$ alkenones were not detected in intertidal sediments examined here, we used the sum of brassicasterol/epi-brassicasterol and dinosterol to represent $\sum P B$ in this study.

The BIT is based on the ratio of GDGTs and has been proposed for estimating the contribution of terrestrial organic matter transported from the soil (Hopmans et al., 2004). BIT is calculated using the following equation:

$$
\begin{aligned}
\mathrm{BIT}= & \left([\mathrm{Ia}]+[\mathrm{IIa}]+\left[\mathrm{IIa}^{\prime}\right]+[\mathrm{IIIa}]+\left[\mathrm{IIIa}^{\prime}\right]\right) /\left([\mathrm{II}]+[\mathrm{IIa}]+\left[\mathrm{IIa}^{\prime}\right]+[\mathrm{IIIa}]\right. \\
& \left.+\left[\mathrm{IIII}^{\prime}\right]+[\mathrm{IV}]\right)
\end{aligned}
$$

where [Ia], [IIa], [IIa'], [IIIa], [IIIa'] are the concentrations of brGDGTs and [IV] is the concentration of crenarchaeol. Isomers for brGDGTs IIa, IIIa were not separated using the analytical method in this study. Molecular structures of GDGTs used in BIT formula can be found in Lopes dos Santos and Vane (2019).

Carbon stock is calculated using the following equation (Avelar et al., 2017):

Carbon stock $(\mathrm{t} / \mathrm{ha})=\mathrm{TOC}(\%) \times \mathrm{BD}\left(\mathrm{g} / \mathrm{cm}^{3}\right) \times$ Depth $(\mathrm{cm})$

$\mathrm{BD}\left(\mathrm{g} / \mathrm{cm}^{3}\right)=$ Solid sediment density $\left(\mathrm{g} / \mathrm{cm}^{3}\right) \times(1-\beta)$

where BD is bulk density of samples and is estimated according to the solid sediment density and porosity $(\beta$ ) (Breen and Orange, 1992). Depth is a given depth interval in the marine sediment. In the present study, carbon stock was calculated for the top $2 \mathrm{~cm}$ depth interval. Carbon stocks from downstream of the Pearl River and Pearl River Delta, downstream of the Yangtze River, the Bohai Sea, the southern inner shelf of the East China Sea were also calculated for the top $2 \mathrm{~cm}$ of sediments using published data (Yu et al., 2010; Zhu et al., 2011; Hu et al., 2012; Liu et al., 2015). Carbon stocks have been reported for the top $10 \mathrm{~cm}$ sediments from the NW European continental shelf and the Exclusive Economic Zone (EEZ) of UK, Namibia and Pakistan (Avelar et al., 2017; Diesing et al., 2017), although the TOC contents were reported for different depth intervals in these sediments. In order to make our results comparable with the published carbon stock values, we re-calculated these values for the top $2 \mathrm{~cm}$ sediments.

\subsection{Binary mixing model}

The fraction of terrestrial OC $\left(\mathrm{F}_{\text {terr }}\right)$ in sediments is defined as follows (Weijers et al., 2009):

$\mathrm{F}_{\text {terr }}=$ Terrestrial OC $(\%)=\left(\mathrm{X}_{\text {Sample }}-\mathrm{X}_{\text {Mar }}\right) /\left(\mathrm{X}_{\text {Terr }}-\mathrm{X}_{\text {Mar }}\right) \times 100 \%$

where $\mathrm{X}_{\text {Sample }}$ is the measured value for each proxy, and $\mathrm{X}_{\mathrm{Mar}}$ and $\mathrm{X}_{\mathrm{Terr}}$ are the marine and terrestrial end member values for each. In this study, terrestrial and marine end-member values of $\delta^{13} \mathrm{C}_{\mathrm{org}}$ were variable due to the large area of sampling stations (Fig. 1). Thus, we used different end-member values of $\delta^{13} C_{\text {org }}$ according to previous studies (Supplementary Table S1). By definition, $X_{\text {Terr }}$ and $\mathrm{X}_{\mathrm{Mar}}$ for TMBR are 1 and 0, respectively (Xing et al., 2011). $\mathrm{X}_{\mathrm{Terr}}$ and $\mathrm{X}_{\mathrm{Mar}}$ for BIT are 0.91 and 0 , respectively. The terrestrial endmember value of the BIT is not 1 because a small quantity of crenarchaeol has been detected in soil (Leininger et al., 2006; Weijers et al., 2004, 2006a) and 0.91 is based on the average BIT values of $>100$ global soil samples (Weijers et al., 2006b, 2007).

\subsection{Statistical analysis}

Principal Component Analysis (PCA) was carried out using IBM SPSS Statistics (Zaghden et al., 2007).

\section{Results}

\subsection{Sediment grain size}

In our study, sediments from the small estuaries were characterized by sandy silt and silt, with the highest average clay contents (21.6\% WS; $12.8 \%$ DS), while those from large estuaries were characterized by silty sand and sandy silt, with intermediate average clay contents (6.0\% WS; 3.3\% DS). In non-estuarine areas, sediments mainly consisted of sand and silty sand, with the lowest average clay contents ( $1.8 \%$ WS; $0.6 \%$ DS) (Table 2 ). In addition, the clay contents values of sediments in WS were generally higher than those in DS (Table 2).

\subsection{Spatial distributions of TOC and $\delta^{13} C_{\text {org }}$}

TOC ranged from $0.03 \%$ to $1.19 \%$ in WS and $0 \%$ to $1.08 \%$ in DS, with values generally higher in WS than those in DS with the exception of site 12 (Fig. 2A; Supplementary Fig. S1A). Average TOC contents showed the highest values in small estuaries $(0.75 \%$ WS; $0.57 \%$ DS), intermediate values in large estuaries $(0.40 \% \mathrm{WS}$; $0.28 \% \mathrm{DS})$ and the lowest values in non-estuarine areas $(0.07 \%$ WS; 0.07\% DS) (Fig. 2A; Supplementary Fig. S1A).

$\delta^{13} \mathrm{C}_{\text {org }}$ values were in the range of $-25.4 \%$ to $-20.4 \%$ in WS and $-24.5 \%$ to $-20.4 \%$ in DS (Fig. 2B). Similar $\delta^{13} C_{\text {org }}$ values were found between WS and DS with the exception of site 4 and site 8 , which showed a relatively large difference between WS and DS (Fig. 2B). Average values were most negative in large estuaries (-23.8\% WS; $-23.6 \%$ DS), intermediate in small estuaries $(-22.4 \%$ WS; $-22.5 \%$ DS), and less negative in non-estuarine areas $(-21.2 \%$ WS; -21.7\%。 DS) (Fig. 2B; Supplementary Fig. S1B).

\subsection{Terrestrial biomarkers}

Long-chain $\Sigma \mathrm{C}_{27+29+31} n$-alkane contents generally showed higher values in WS (23.6 to $956 \mathrm{ng} / \mathrm{g}$ ) than those in DS (11.8 to $661 \mathrm{ng} / \mathrm{g})$. The maximum values for both WS and DS were found at site 11 (a small estuary) (Fig. 3A; Supplementary Fig. S1C). The highest average values were found in small estuaries (553 ng/g WS; $488 \mathrm{ng} / \mathrm{g}$ DS), intermediate average values in large estuaries (367 ng/g WS; $176 \mathrm{ng} / \mathrm{g} \mathrm{DS}$ ), lowest average values in 
Table 2

Grain size and sediment types of surface sediments at the 14 sampling sites.

\begin{tabular}{|c|c|c|c|c|c|c|c|c|c|c|c|c|c|}
\hline & \multirow[t]{2}{*}{ Site No. } & \multicolumn{6}{|c|}{ WS sediment grain size (\%) } & \multicolumn{6}{|c|}{ DS sediment grain size (\%) } \\
\hline & & $\begin{array}{l}\text { Clay } \\
<4 \mu \mathrm{m}\end{array}$ & $\begin{array}{l}\text { Silt } \\
4-63 \mu \mathrm{m}\end{array}$ & $\begin{array}{l}\text { Sand } \\
>63 \mu \mathrm{m}\end{array}$ & Types & $\begin{array}{l}\text { Avg. clay } \\
\text { content }\end{array}$ & $\begin{array}{l}\text { Median } \\
\text { grain size } \\
(\mu \mathrm{m})\end{array}$ & $\begin{array}{l}\text { Clay } \\
<4 \mu \mathrm{m}\end{array}$ & $\begin{array}{l}\text { Silt } \\
4-63 \mu \mathrm{m}\end{array}$ & $\begin{array}{l}\text { Sand } \\
>63 \mu \mathrm{m}\end{array}$ & Types & $\begin{array}{l}\text { Avg. clay } \\
\text { content }\end{array}$ & $\begin{array}{l}\text { Median } \\
\text { grain size } \\
(\mu \mathrm{m})\end{array}$ \\
\hline \multirow{5}{*}{$\begin{array}{l}\text { Small estuaries } \\
\quad \text { (river discharges } \\
\quad<50 \text { billion } \mathrm{m}^{3} / \mathrm{a} \text { ) }\end{array}$} & 1 & 17 & 59 & 24 & Sandy silt & & 23 & 16 & 58 & 26 & Sandy silt & 12.8 & 24 \\
\hline & 3 & 27 & 69 & 4 & Silt & & 8 & 16 & 79 & 5 & Silt & & 18 \\
\hline & 6 & 26 & 71 & 3 & Silt & 21.6 & 8 & 15 & 67 & 18 & Sandy silt & & 23 \\
\hline & 9 & 12 & 83 & 5 & Silt & & 20 & 6 & 92 & 2 & Silt & & 24 \\
\hline & 11 & 26 & 68 & 6 & Silt & & 9 & 11 & 83 & 7 & Silt & & 21 \\
\hline \multirow{4}{*}{$\begin{array}{l}\text { Large estuaries } \\
\quad(\text { river discharges } \\
\quad>50 \text { billion } \mathrm{m}^{3} / \mathrm{a} \text { ) }\end{array}$} & 4 & 5 & 62 & 33 & Sandy silt & & 50 & 3 & 22 & 75 & Silty sand & 3.3 & 86 \\
\hline & 8 & 4 & 69 & 27 & Sandy silt & 6.0 & 45 & 4 & 86 & 10 & Silt & & 25 \\
\hline & 10 & 15 & 43 & 42 & Sandy silt & & 30 & 1 & 12 & 87 & Silty sand & & 216 \\
\hline & 12 & 0 & 0 & 100 & Sand & & 234 & 5 & 57 & 38 & Sandy silt & & 198 \\
\hline \multirow[t]{5}{*}{ Non-estuaries } & 2 & 0 & 0 & 100 & Sand & & & 0 & 0 & 100 & Sand & 0.6 & \\
\hline & 5 & 0 & 0 & 100 & Sand & & & 0 & 0 & 100 & Sand & & \\
\hline & 7 & 1 & 52 & 47 & Sandy silt & 1.8 & 62 & 0 & 41 & 59 & Silty sand & & 68 \\
\hline & 13 & 4 & 17 & 79 & Silty sand & & & 1 & 8 & 91 & Sand & & \\
\hline & 14 & 4 & 14 & 82 & Silty sand & & 119 & 2 & 24 & 74 & Silty sand & & 100 \\
\hline
\end{tabular}
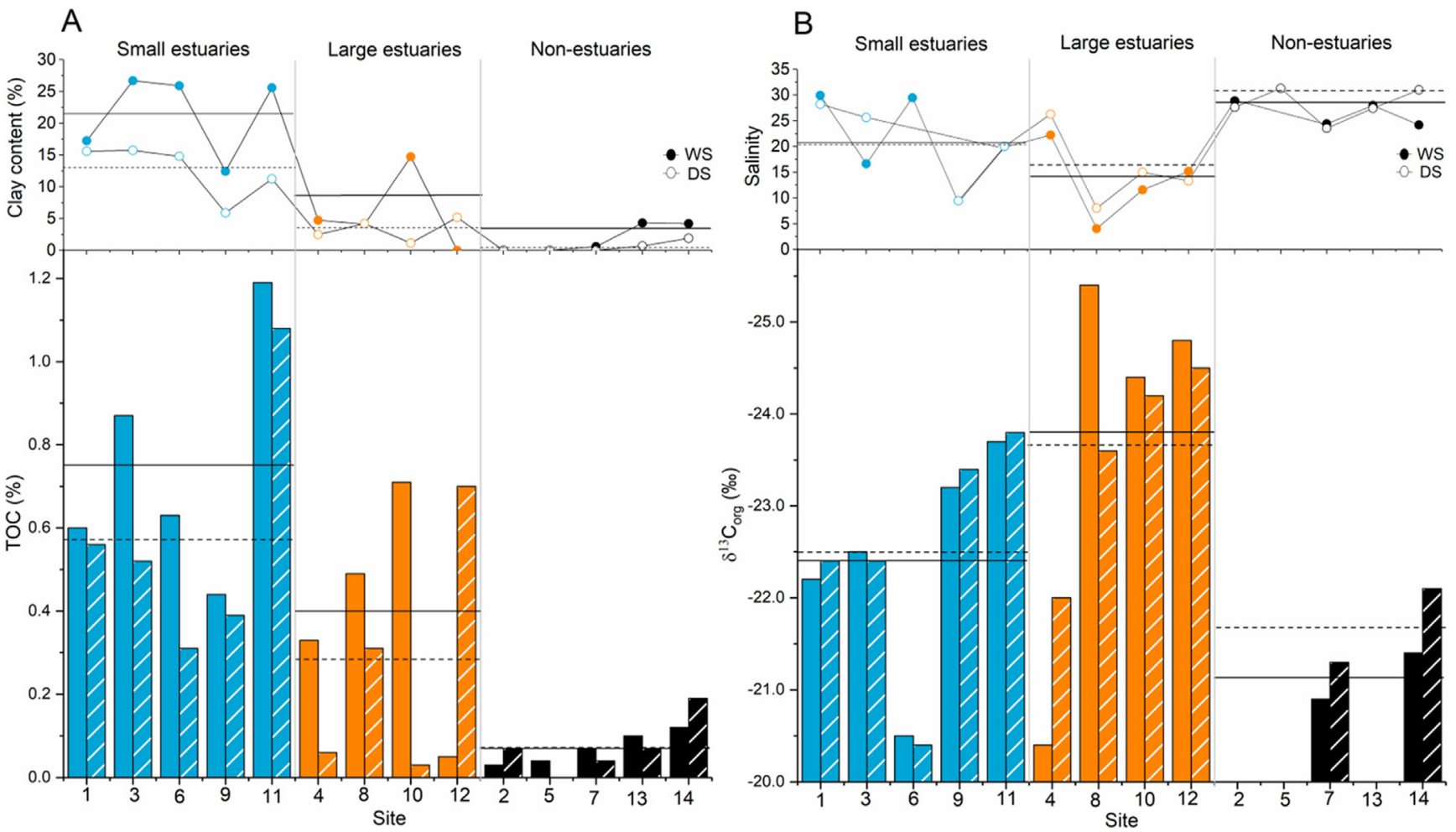

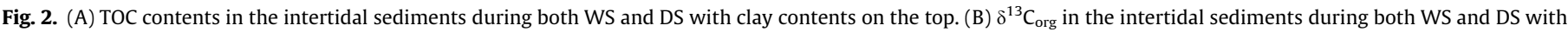

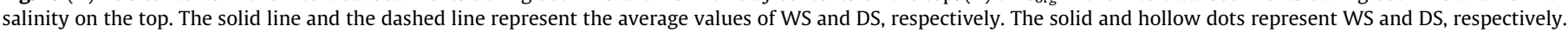

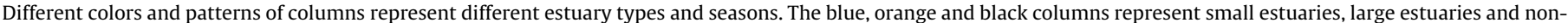

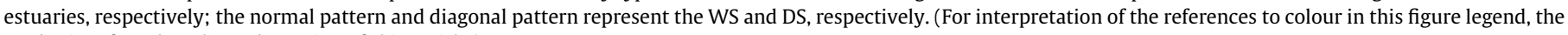
reader is referred to the web version of this article.)

non-estuaries (94 ng/g WS; 79 ng/g DS) (Fig. 3A; Supplementary Fig. S1C).

The contents of brGDGTs ranged from 3.1 to $286 \mathrm{ng} / \mathrm{g}$ and 1.2 to $358 \mathrm{ng} / \mathrm{g}$ in WS and DS, respectively. The maximum value in WS occurred at site 10 (286 ng/g, a large estuary), while that in DS was found at site 11 (358 ng/g, a small estuary) (Fig. 3B; Supplementary Fig. S1E). Generally, average brGDGTs contents were similar between small estuaries ( $81 \mathrm{ng} / \mathrm{gWS} ; 125 \mathrm{ng} / \mathrm{g}$ DS) and large estuaries ( $89 \mathrm{ng} / \mathrm{g}$ WS; $83 \mathrm{ng} / \mathrm{g}$ DS), while they were the lowest in nonestuaries (14 ng/g WS; 21 ng/g DS) (Fig. 3B; Supplementary Fig. S1E).

\subsection{Aquatic biomarkers}

The contents of phytoplankton biomarkers $\Sigma$ PB varied from 0 to $923 \mathrm{ng} / \mathrm{g}$ in WS and 40 to $978 \mathrm{ng} / \mathrm{g}$ in DS, with the maximum values for both WS and DS at site 11 (a small estuary) (Fig. 3C; Supplementary Fig. S1D). The highest average values for both WS (554 ng/g) and DS (560 ng/g DS) also occurred in small estuaries, and lower and similar average values were found in large $(231 \mathrm{ng} / \mathrm{g}$ ) and non-estuaries (248 ng/g) during DS (Fig. 3C; Supplementary Fig. S1D). 

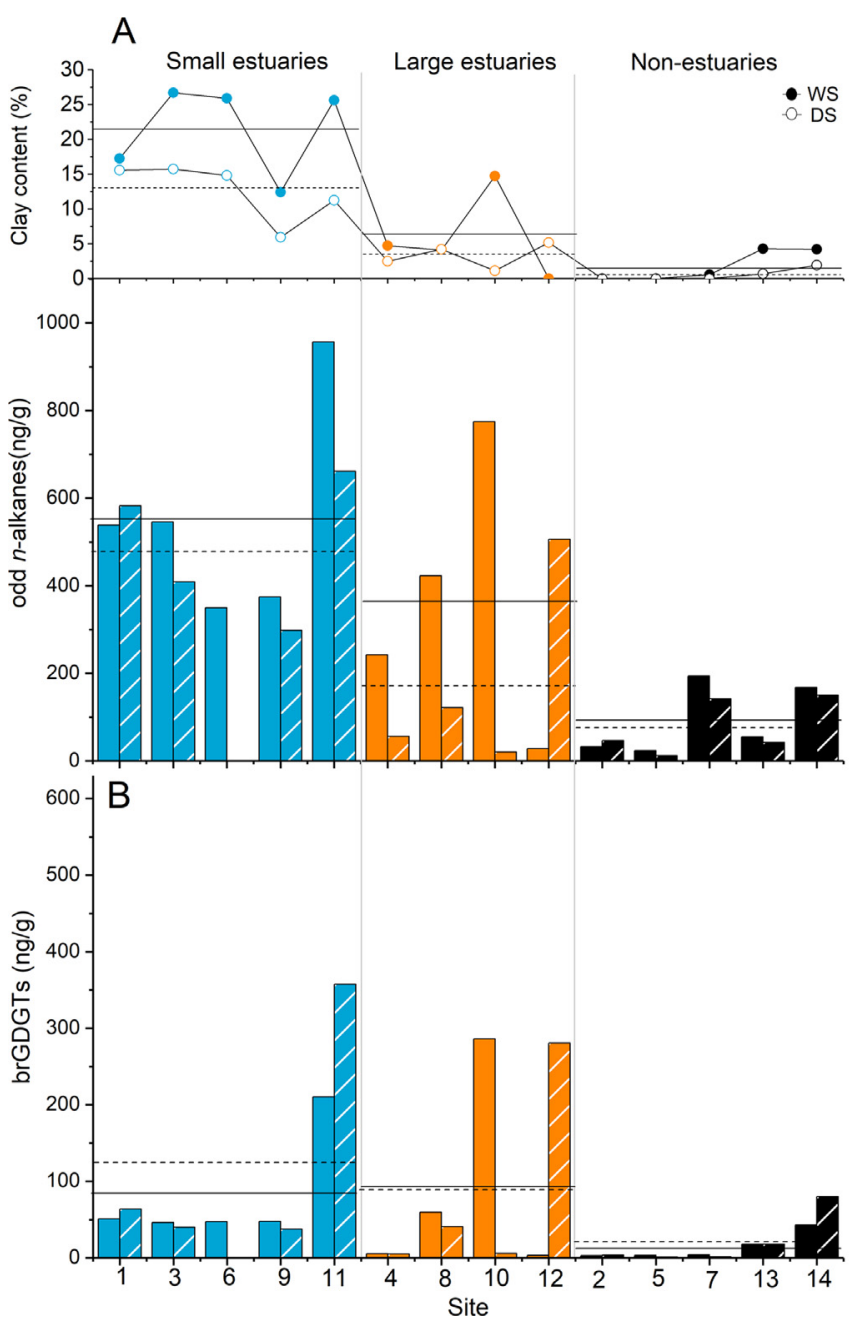
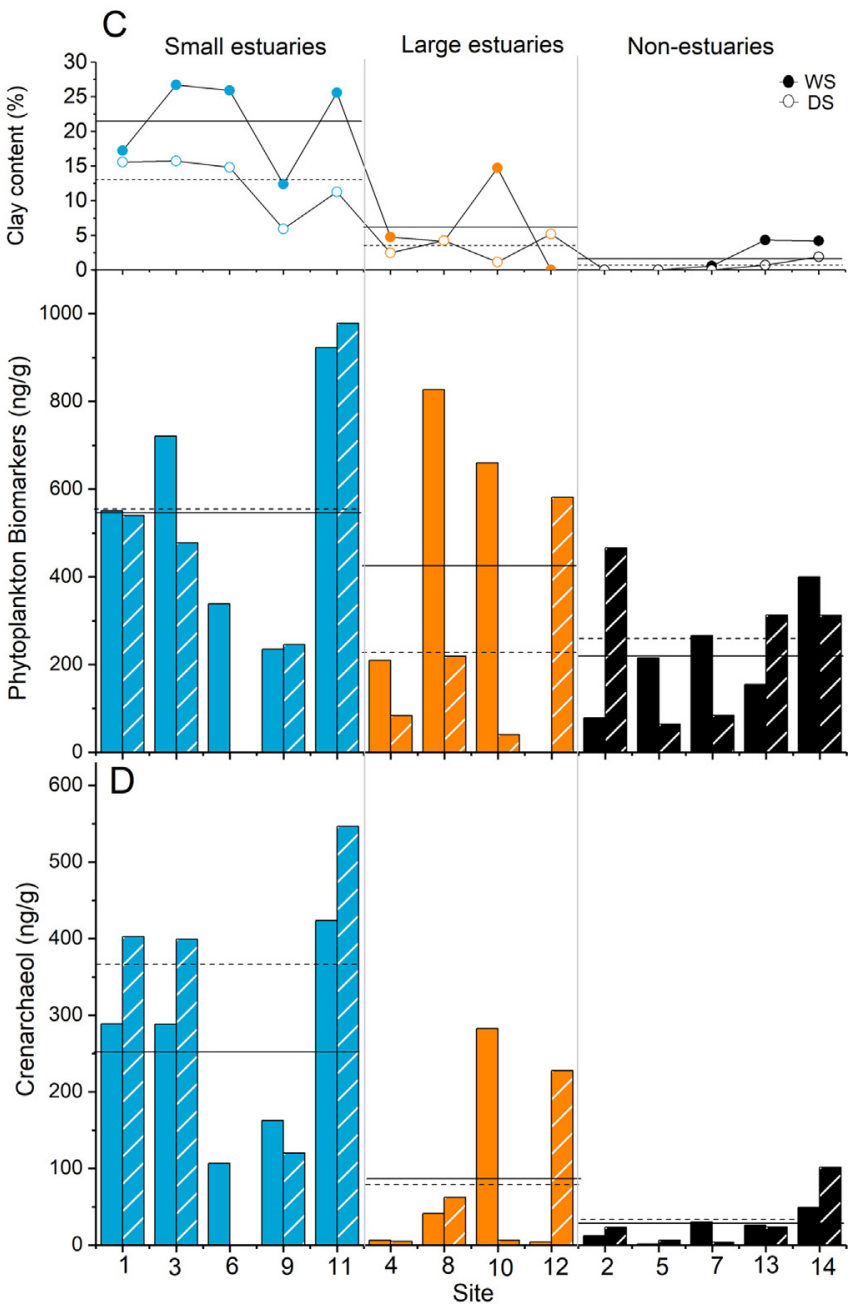

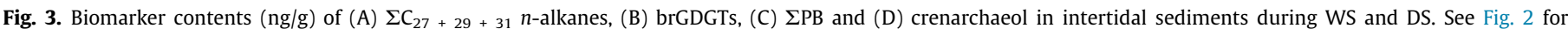
explanations of the different patterns and colors of lines, dots and columns.

Crenarchaeol contents ranged from 1.5 to $424 \mathrm{ng} / \mathrm{g}$ in WS and 3.5 to $547 \mathrm{ng} / \mathrm{g}$ in DS, with maximum values for both WS and DS at site 11 (Fig. 3D; Supplementary Fig. S1F). Average values were the highest in small estuaries (254 ng/g WS; $367 \mathrm{ng} / \mathrm{g}$ DS), intermediate in large estuaries ( $84 \mathrm{ng} / \mathrm{g}$ WS; $75 \mathrm{ng} / \mathrm{g} \mathrm{DS}$ ), the lowest in non-estuaries (24 ng/g WS; 32 ng/g DS) (Fig. 3D; Supplementary Fig. S1F).

\section{Discussion}

Sediment properties in intertidal zones can be very heterogeneous, especially for intertidal zones close to the estuaries. For example, Yu et al. (2010) analyzed surface sediments from the shallow water of the Pearl River Estuary and found the bulk properties of sediments varied dramatically. To minimize the variabilities of sediment properties in each individual intertidal zone in our study, the samples were collected from the low tide level where the sedimentary environment was relatively stable and less subject to external disturbances (including anthropogenic, biological or hydrodynamic) compared to high- and mid-tidal levels (Liu and Han, 2016). This preliminary study focused on the comparisons of spatial and seasonal variations of sedimentary OC distribution among different types of intertidal zones in China, and we hypothesize that these variations among different types of intertidal zones should be larger than that within individual intertidal zones.

\subsection{Grain size influences of OC distributions in intertidal sediments}

The OC stability in marine sediments depends, to a great degree, on its association with minerals. Grain size is a key property for OC protection, and minerals are sorted by wave mixing and redistribution (Volkman et al., 2000). In our study, the TOC and clay contents in intertidal sediments showed a statistically significant positive correlation in WS $\left(R^{2}=0.82, P<0.05\right.$; Supplementary Fig. S2A), but this correlation was not statistically significant in DS. Generally, sedimentary TOC contents during WS were obviously higher than those during DS (Fig. 2A; Supplementary Fig. S1A), because the clay contents in sediments during WS were generally higher than those during DS, with the one exception of the Pearl River Estuary (Fig. 2A). Our estuarine results are broadly consistent with a previous study that reported a linear relationship between sedimentary TOC and clay contents in the Bohai Sea (Hu et al., 2009).

During WS, higher riverine input contributed a large proportion of fine materials to sediments. While during DS, reduced riverine input together with the strong coastal erosion of fine particles resulted in a smaller proportion of fine materials (Venkatramanan et al., 2014; Yang et al., 2017). Higher contents of both terrestrial and marine biomarkers during WS (Fig. 3) can be attributed to the increasing terrestrial organic matter input via much stronger riverine flow and phytoplankton blooms during WS, respectively (Pinckney et al., 1998; Dagg et al., 2004). In addition, different sedimentary TOC and biomarker contents among 
small, large and non-estuaries (Figs. 2 and 3) in intertidal zones along China's coastline are largely due to the different sedimentary environment (e.g., grain size) (Fig. 4; Table 2).

\subsubsection{High OC and biomarker contents in small estuary intertidal zones}

In small estuaries, the fine particles are easily deposited under weak river discharges, resulting in high clay contents in sediments (Table 2). Because the fine particles can protect OC more efficiently (Volkman et al., 2000), generally highest contents of TOC and biomarkers (both terrestrial and marine) occurred in sediments from small estuaries (Fig. 2A and 3; Supplementary Fig. S1). This was also supported by the PCA analyses of these proxies (Fig. 4).

Differences of TOC and biomarker contents among small estuary sites are likely caused by various local factors. The highest contents of TOC and biomarkers at site 11 (Jiulong River Estuary) (Figs. 2A and 3) are related to algal blooms fertilized by the balanced ratio of nitrogen and phosphorus loading (Li et al., 2011). Simultaneously, the frequent occurrences of typhoons in the vicinity of Taiwan Strait drives large amounts of terrestrial OC to coastal sediments (Shiah et al., 2000; Hung and Gong, 2011). These processes resulted in high sedimentary TOC at site 11 , in addition to the preservation effect associated with high clay contents (Supplementary Fig. S2A). Site 9 is located at the funnel-shaped, tidedominated Qiantang River Estuary (Yu et al., 2012), characterized by a large sand bar and much coarser sediments than other small estuary sites (Table 2). Thus, both TOC and biomarker contents had below average values at small estuary sites (Figs. 2A and 3). The strong tide in the vicinity of the Qiantang River Estuary causes intense resuspension of sediments, leading to a high turbidity in the watersheds, which inhibits the growth of marine phytoplankton, resulting in the lowest contents of $\sum$ PB (Zhang et al., 2009). Site 1 (Liao River Estuary), site 3 (Jian River Estuary) and site 6 (Dagu River Estuary) are all located along the Bohai Sea-Yellow Sea coastline, showing broadly similar distribution of TOC and biomarker contents (Figs. 2A and 3). Site 1 and site 3 results are consistent with the similar contents of particulate organic carbon (POC) in these two estuaries (Xia and Zhang, 2011). Site 6 values were in the range of those from the downstream of Dagu River (K. Liu, unpublished data), caused by the current reversals in the vicinity of the Dagu River Estuary (Chen et al., 2016). Thus, these small contents of estuarine OC and biomarkers are closely related to their riverine input.

\subsubsection{Low OC and biomarker contents in non-estuarine intertidal zones}

Clay contents in non-estuarine intertidal zones without the influence of river discharge are controlled by intertidal dynamics which could cause re-suspended fine sediments to be transported to deeper water, resulting in coarse sediments in the intertidal zones (Ke et al., 1996; Malvarez et al., 2001). In this study, the lowest contents of both TOC and biomarkers occurred in non-estuarine intertidal zones where sediments were significantly coarse (Figs. 2A and 3; Table 2; Supplementary Fig. S1). Generally, higher TOC and biomarker contents were found in sites from the south of China (site 13 Yingluo Bay and site 14 Dongzhai Bay) than those from the north of China (sites 2, 5 and 7), because the warmer climate is suitable for the growth of both phytoplankton and plants (Peeters et al., 2010). Mangrove ecosystems are well-developed at site 13 in Yingluo Bay and at site 14 in Dongzhai Bay, contributing a significant amount of $O C$ to the intertidal sediments there (Nie, 2018). However, relatively high phytoplankton biomarker contents in sediments of DS were found at site 2 Qinhuangdao Shoal (Fig. 3C), synchronous with high brassicasterol/epi-brassicas terol contents at this site (Supplementary Fig. S3A). This was supported by a previous study that diatoms in the Qinhuangdao coastal area usually become abundant during DS due to higher concentration of silica and phosphorus (Xu et al., 2017).

\subsubsection{Variable OC and biomarker contents in large estuary intertidal zones}

In a large estuary, strong water discharge could result in the transport and deposition of coarser sediments (Abballe and Chivas, 2017; Yang et al., 2017). Thus, clay contents in large estuary intertidal zones are generally lower than those in small estuaries (Table 2), resulting in lower sedimentary TOC and biomarker contents (Figs. 2A and 3; Supplementary Fig. S1). At site 4 in the Yellow River Estuary, high turbidity caused by sediment resuspension (Wang and Wang, 2010) inhibited primary productivity, an important factor for very low contents of phytoplankton biomarkers and overall lower TOC contents (Figs. 2A and 3C). This was consistent with studies of other large estuaries where turbidity primarily controls gross primary productivity (e.g., RochelleNewall et al., 2011). However, significantly higher $\Sigma$ PB contents in sediments with low clay contents during WS were found at site 8 in the Yangtze River Estuary (Fig. 3C). This was likely caused by an increased nutrient input during WS from the Yangtze River (Zhou et al., 2008; Jiang et al., 2014; Wang et al., 2014), which
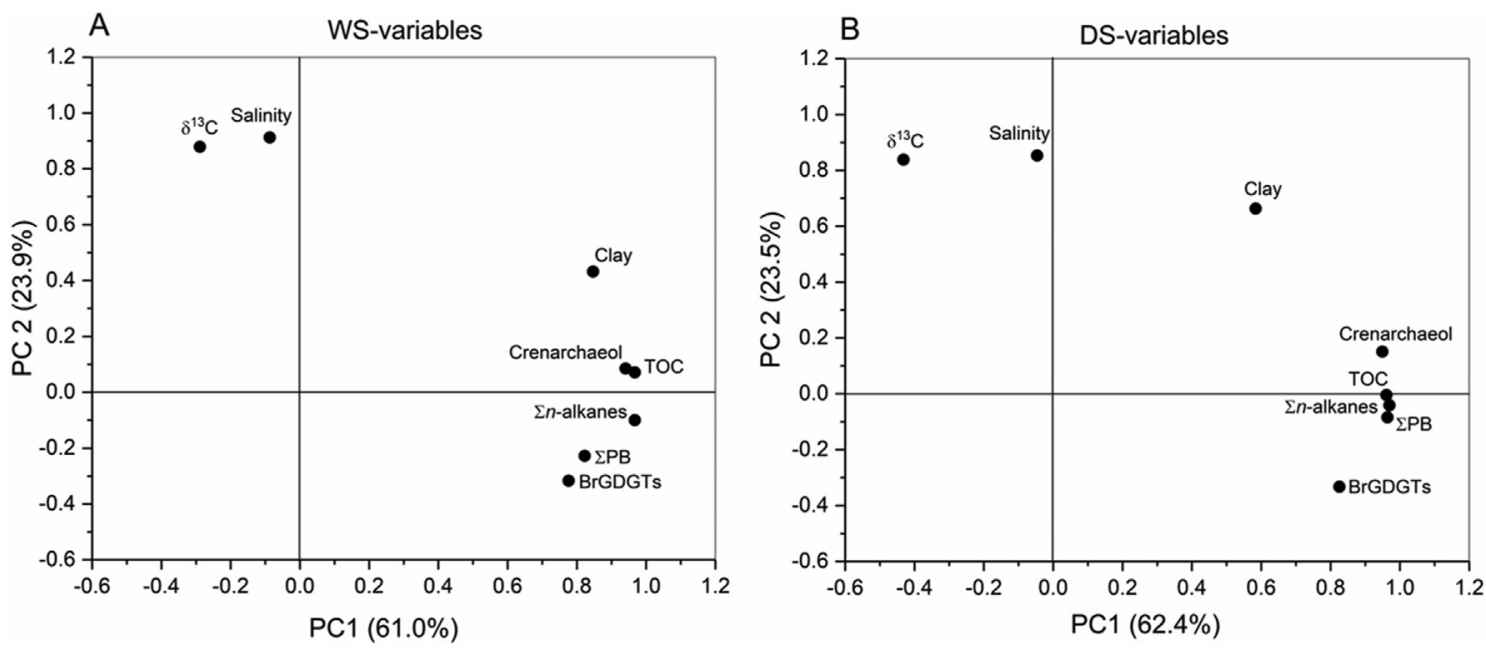

Fig. 4. PCA of the multiple proxies used in present study during: (A) WS and (B) DS. 
increased overall phytoplankton productivity (Liu et al., 2009; Yu et al., 2015) and dinoflagellate productivity as reflected by the highest dinosterol contents in sediments of WS (Supplementary Fig. S3B). Similarly, higher phytoplankton biomarker contents occurred in both suspended particles and sediments of the Yangtze River Estuary (Hu et al., 2012; Bi et al., 2018). The large difference in TOC and biomarker contents between WS and DS at site 10 in the Minjiang River Estuary is related to the relatively high clay contents during WS but very low clay contents during DS (Table 2). The $100 \%$ sandy sediment at site 12 in the Pearl River Estuary in WS may be partially attributed to intense hydrodynamic forces driven by the strong river discharge during WS, causing resuspension and mobilization of fine particles with deposition of coarse particles (Dong et al., 2006). A previous study reported that 95\% of the suspended sediment from the Pearl River Estuary was discharged during the WS (Dong et al., 2006). Consequently, terrestrial and marine biomarkers and TOC at site 12 in the Pearl River Estuary during WS were all below the detection limit (Figs. 2A and 3).

\subsection{Quantitative estimates of terrestrial and marine OC contributions in intertidal sediments}

The contributions of terrestrial and marine $\mathrm{OC}$ to sedimentary TOC in intertidal zones in China are closely related to the salinity, as the values of terrestrial OC proxy of $\delta^{13} C_{\text {org }}$ showed a positive relationship with salinity $\left(R^{2}=0.64, P<0.05\right.$ in $W S ; R^{2}=0.53$, $\mathrm{P}<0.05$ in DS; Supplementary Fig. S2B). PCA also showed a strong association of $\delta^{13} \mathrm{C}_{\text {org }}$ and salinity (Fig. 4). More negative average $\delta^{13} C_{\text {org }}$ values (more terrestrial OC) were found in large estuary intertidal zones with lower salinity (Fig. 2B; Supplementary Fig. S2B), because strong riverine discharge simultaneously transported more terrestrial $O C$ to the estuary and diluted the salinity (Uncles and Lewis, 2001; Díez-Minguito et al., 2013). In contrast to the large estuaries, less negative $\delta^{13} \mathrm{C}_{\mathrm{org}}$ values and high salinity occurred in non-estuaries due to the lack of riverine input (Fig. 2B; Supplementary Fig. S2B), indicating that a saline marine environment favored marine primary productivity. In small estuaries, average $\delta^{13} \mathrm{C}_{\text {org }}$ values revealed the mixing of terrestrial and marine $\mathrm{OC}$ contribution and salinity showed a large range (Fig. 2B; Supplementary Fig. S2B).

OC source identification is complicated by potential modification of end-member signatures via biogeochemical processes which are known to alter the isotopic and elemental composition of OC pools in estuaries (Liu et al., 2006). We used a simple binary mixing model with different sets of indices $\left(\delta^{13} C_{\text {org }}\right.$, TMBR and BIT) to estimate the fraction of terrestrial $\mathrm{OC}\left(\mathrm{F}_{\text {terr }}\right)$ in the intertidal sediments. Although some differences in proportions were found using $\delta^{13} \mathrm{C}_{\mathrm{org}}$, TMBR and BIT (Fig. 2B; Supplementary Fig. S4), terrestrial OC fractions based on these three indices all showed positive correlations with terrestrial biomarker contents (Supplementary Fig. S5).

Table 3 compares the average values of the terrestrial OC fractions based on $\delta^{13} \mathrm{C}$, TMBR and BIT from three types of estuarine intertidal zones during both WS and DS. First, there was no obvious difference in terrestrial OC fractions between WS and DS based on each index (Fig. 2B and 5; Table 3; Supplementary Fig. S6).
However, the terrestrial OC fractions showed variable values calculated by the different indices (Fig. 5; Table 3; Supplementary Fig. S6). $\mathrm{F}_{\text {terr }}-\delta^{13} \mathrm{C}_{\text {org }}$ showed highest values in large estuaries (avg. 61\%), while lowest values in non-estuaries (avg. 24.5\%) (Table 3 ). In contrast, F $_{\text {terr }}$-TMBR showed highest values in small estuaries (avg. 46.5\%) and lowest values in non-estuaries (avg. $24.5 \%$ ); $\mathrm{F}_{\text {terr }}$-BIT showed highest values in large estuaries (avg. $54 \%$ ) and lowest values in small estuaries (avg. 24.5\%) (Table 3). One reason for these differences is that $\delta^{13} C_{\text {org }}$ is measured for TOC while TMBR and BIT are based on biomarkers that only account for a small percentage of TOC $(<1 \%)$ (Zhao et al., 2006 and References therein). In addition, the $\sum n$-alkanes as terrestrial OC endmembers in the TMBR could be complicated by the presence of significant amount of petrogenic and fossil fuel OC in terrestrial OC (Bianchi et al., 2018). In our study, the carbon preference index (CPI) values of 1.03 and 1.17 in Minjiang River and Sishiliwan Shoal during DS imply major contributions from fossil hydrocarbon sources, also supported by the presence of a UCM (unresolved complex mixture) in the $n$-alkane chromatograms (Gao and Chen, 2008; Supplementary Fig. S7). On the other hand, phytoplankton biomarkers in marine sediments could be influenced by the input of freshwater diatom-produced biomarkers (Gaiser and Johansen, 2000). Also, the local endmembers for BIT can vary considerably and BIT can be as low as 0.7 in some soils (Weijers et al., 2006b). The lack of a local BIT endmember value limited its use for calculating terrestrial OC sources in our study. Thus, there were major limitations of using both the TMBR and BIT to quantify terrestrial OC sources in intertidal zones; we therefore used the $\delta^{13} C_{\text {org }}$ as a proxy for terrestrial OC to further quantify $\mathrm{OC}$ spatial distributions and controlling factors.

First, high terrestrial OC contributions were found in large estuary intertidal zones. Based on $\mathrm{F}_{\text {terr }}-\delta^{13} \mathrm{C}_{\mathrm{org}}$, terrestrial OC contributed about $62-80 \%$ to sedimentary TOC in large estuary intertidal zones, except at site 4 in the Yellow River Estuary (24\%) (Fig. 5). Coincidentally, the $\delta^{13} \mathrm{C}_{\text {org }}$ values in sediments from this site were less negative during both WS and DS, especially with the more enriched $\delta^{13} \mathrm{C}_{\text {org }}$ value during WS $(-20.4 \%$, close to the marine end member) (Fig. 2B), probably influenced by the contribution of aquatic phytoplankton (Zhang et al., 2010; Hu et al., 2016). This is consistent with a previous study that reported a range of $\delta^{13} \mathrm{C}_{\text {org }}$ values in sediments from the Yellow River Delta from $-24.3 \%$ o to $-20.4 \%$ (Dai et al., 2017). These enriched values might be attributed to the contribution of aquatic phytoplankton in the Yellow River (Zhang et al., 2010; Hu et al., 2016). In contrast, terrestrial OC contributions were $>60 \%$ in other large estuaries in our study (Yangtze River, Minjiang River and Pearl River estuaries).

Second, low terrestrial OC contributions were found in nonestuarine intertidal zones. Lack of riverine input resulted in a range of $13-15 \%$ terrestrial OC based on $\delta^{13} C_{\text {org }}$ (Fig. 5). However, $\delta^{13} C_{\text {org }}$ was only measured at two stations (site 7 Subei shoal and site 14 Dongzhai Bay) in non-estuarine intertidal zones, because the TOC contents for the other sites were too low due to the coarse sediments (Fig. 3B).

Finally, variable OC contributions were found in small estuary intertidal zones. Most sites in small estuary intertidal zones were characterized by low terrestrial OC contributions (3-35\%) (Fig. 5).

Table 3

Average values of the terrestrial OC fractions in sediments based on $\delta^{13} \mathrm{C}_{\mathrm{org}}$, TMBR and BIT from three types of estuarine intertidal zones during both WS and DS.

\begin{tabular}{|c|c|c|c|c|c|c|c|c|c|}
\hline & \multicolumn{3}{|c|}{$\underline{\text { Small estuaries }}$} & \multicolumn{3}{|c|}{$\underline{\text { Large estuaries }}$} & \multicolumn{3}{|c|}{ Non-estuaries } \\
\hline & WS & DS & Average & WS & DS & Average & WS & DS & Average \\
\hline $\mathrm{F}_{\text {terr }}-\delta^{13} \mathrm{C}_{\mathrm{org}}(\%)$ & 39 & 40 & 39.5 & 61 & 61 & 61.0 & 10 & 19 & 24.5 \\
\hline $\mathrm{F}_{\text {terr }}-\mathrm{TMBR}(\%)$ & 47 & 46 & 46.5 & 43 & 41 & 42.0 & 25 & 24 & 24.5 \\
\hline $\mathrm{F}_{\text {terr }}-\mathrm{BIT}(\%)$ & 25 & 24 & 24.5 & 55 & 53 & 54.0 & 41 & 30 & 35.5 \\
\hline
\end{tabular}


Notably the lowest terrestrial OC contributions were found at site 6 in the Dagu River Estuary, probably related to the development of $\mathrm{C}_{4}$ plants (e.g., Spartina alterniflora Loisel) (Zhang et al., 2010). However, much higher $\mathrm{F}_{\text {terr }}-\delta^{13} \mathrm{C}_{\text {org }}$ was found at site 9 in the Qiantang River Estuary (59\%) and at site 11 in the Jiulong River Estuary (67\%), which were influenced by additional terrestrial material input from river and typhoon, respectively (Shiah et al., 2000; Hung and Gong, 2011; Wang, 2017). A previous study reported

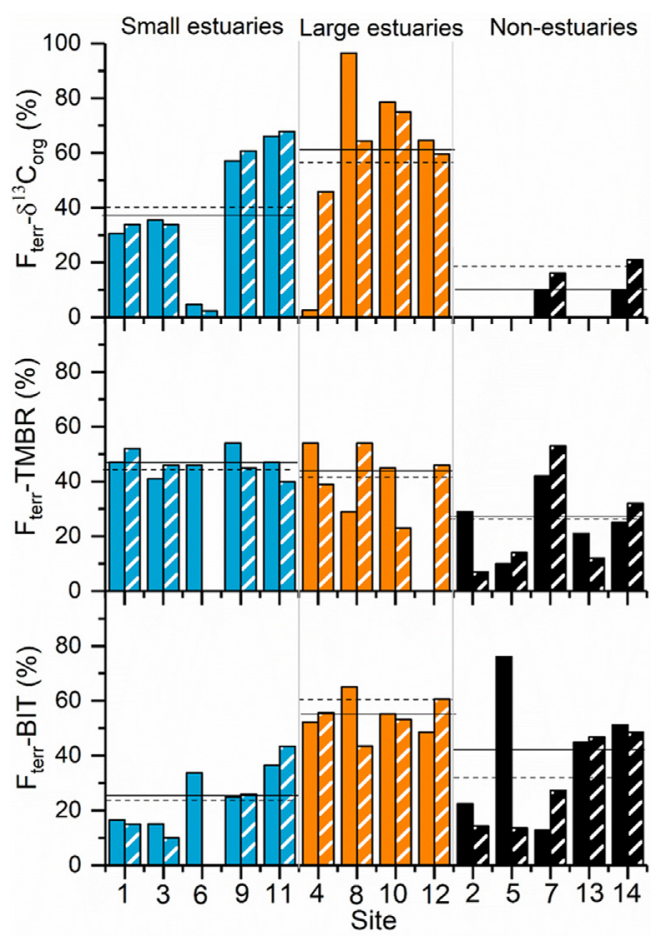

Fig. 5. Estimates of the terrestrial $O C$ fractions in intertidal sediments using a binary mixing model based on $\delta^{13} \mathrm{C}_{\text {org }}\left(\mathrm{F}_{\text {terr }}-\delta^{13} \mathrm{C}_{\text {org }}\right)$, TMBR $\left(\mathrm{F}_{\text {terr }}\right.$-TMBR $)$ and BIT $\left(\mathrm{F}_{\text {terr }}-\mathrm{BIT}\right)$. For interpretations of the different patterns and colors of lines and columns see Fig. 2 . that terrestrial OC contributions were 53-59\% in Hangzhou Bay (Zhang et al., 2009; where site 9 Qiantang is located), consistent with our estimates of terrestrial $\mathrm{OC}$ fractions. The $\delta^{13} \mathrm{C}_{\text {org }}$ values of sediments with grain size $>63 \mu \mathrm{m}$ were $-26 \%$ to $-25 \%$ (Zhang et al., 2009), indicating that the coarse contents in sediments from Hangzhou Bay contain terrestrial plant debris. This was also supported by the microscopic analysis (Zhang et al., 2009).

\subsection{Sedimentary $O C$ in intertidal zones: perspective from the carbon stock}

Processes controlling sedimentary OC in coastal areas have been defined through a study of "hot spots" in the global ocean (Bianchi et al., 2018). As the main land-ocean interface, intertidal zones with high OC variations are of significant importance for the global carbon cycle. Previous studies have pointed out that approximately $114 \mathrm{Tg}$ C/year and $70 \mathrm{Tg}$ C/year are buried in river deltas and nondeltaic shelf areas, while only $6 \mathrm{Tg} \mathrm{C} /$ year is buried in the open ocean (Burdige, 2005). Similar to our study, estuarine intertidal zones accumulated more sedimentary OC than non-estuarine intertidal zones (Fig. 2A; Supplementary Fig. S1A). In particular, estuarine intertidal zones are strongly influenced by anthropogenic activities, including both nutrient and organic matter inputs. For example, increasing terrestrial nutrient input to the Yangtze River Estuary during WS favored marine primary productivity (Zhou et al., 2008; Jiang et al., 2014; Wang et al., 2014), supported by high phytoplankton biomarker contents at site 8 in our study (Fig. 3C). However, the direct OC contributions from anthropogenic influences (sewage discharge, aquaculture and fossil fuel combustion, etc.) are hard to estimate.

Recently, a carbon stock index has been proposed to quantify the amount of carbon storage in a reservoir or system, including terrestrial ecosystems, anthropogenic sources and the atmosphere (Avelar et al., 2017). In the present study, we assessed the carbon stocks of intertidal zones along the coastline of China, including the organic matter from land, ocean and human activities (Avelar et al., 2017), to comprehensively evaluate the role of intertidal zones as sedimentary OC reservoirs. The distributions of carbon stocks were similar to that of TOC, clay contents and biomarkers, showing generally highest average values in small estuary inter-
A

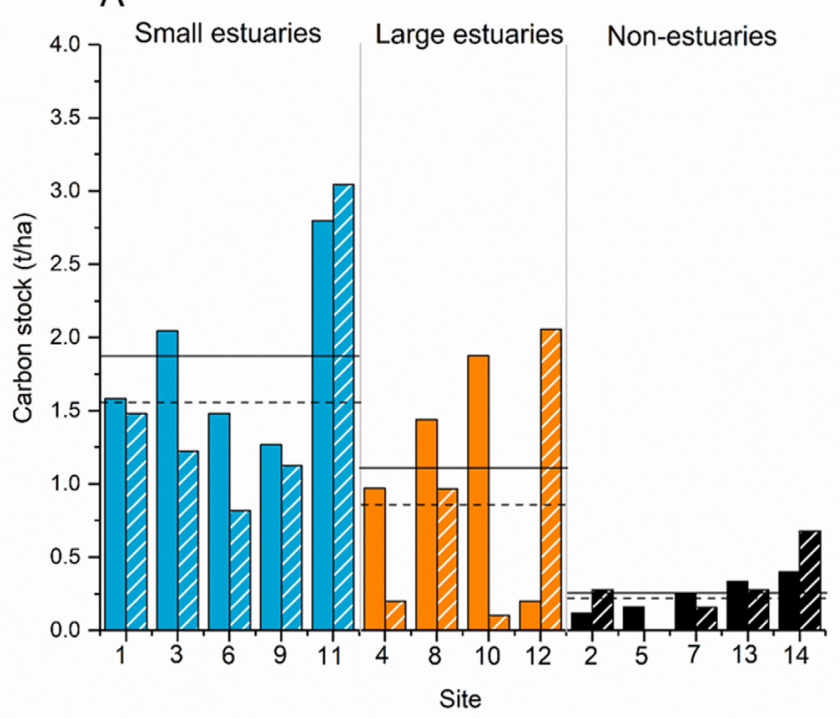

B

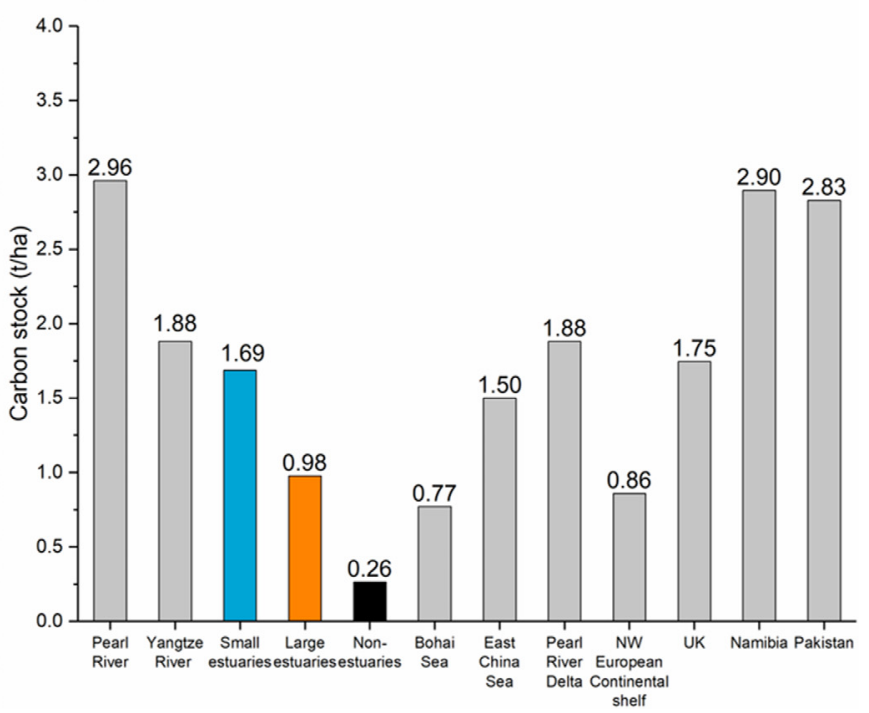

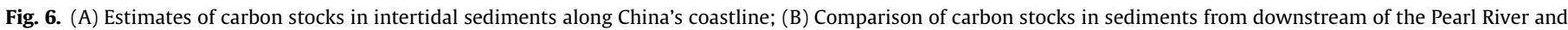

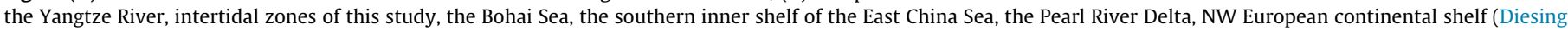
et al., 2017) and the EEZ (UK, Namibia and Pakistan; Avelar et al., 2017). For interpretations of the different patterns and colors of lines and columns see Fig. 2. 
tidal zones, intermediate average values in large estuary intertidal zones and lowest average values in non-estuarine intertidal zones (Fig. 6A).

We compared OC stocks in sediments from downstream of the Pearl River and the Yangtze River, intertidal zones, marginal seas and the EEZ to give a spatial perspective for the river-estuarymarine systems. We found these values were in the same order of magnitude (Fig. 6B). The carbon stock values in intertidal sediments along China's coastline were generally lower than those from large rivers and the Pearl River Delta in China and the EEZ of UK, Namibia and Pakistan while comparable to those from the Bohai Sea, the East China Sea and NW European continental shelf (Fig. 6B; Avelar et al., 2017; Diesing et al., 2017). This may be attributed to the degradation of OC during the transport from the river to its estuary and the resuspension of fine materials in the intertidal zones (Dong et al., 2006; Middelburg and Herman, 2007). However, the sedimentation rates in the intertidal zones of our study (0.1-5 cm/year) (Hu et al., 2011; Xu et al., 2012) were much higher than those from shelf regions (a few $\mathrm{cm}$ to several tens of $\mathrm{cm} / 1000 \mathrm{yr}$ ) (Middelburg et al., 1997). Relatively high accumulation rates of OC in intertidal zones provide evidence for their important role as OC reservoirs. Thus, carbon stocks in intertidal environments between terrestrial and marine realms should be considered as a part of national greenhouse gas inventories (Avelar et al., 2017). Comprehensive data measurements and comparisons in future studies are of great importance for assessing human activities impacting carbon stocks of coastal areas and for further understanding the global carbon cycle.

\section{Conclusions}

The distribution of sedimentary OC was investigated in 14 different intertidal zones along China's coastline during the wet (WS) and the dry (DS) seasons. Our results showed spatial and seasonal variations of sedimentary OC between different intertidal zones, which were primarily controlled by the preservation conditions (grain size). OC contents and carbon stocks were higher in the WS than the DS mainly due to higher inputs in the WS. Small estuary intertidal zones were characterized by higher sedimentary OC content and carbon stock owing to the high clay contents, caused by weak hydrodynamic processes, and by variable terrestrial OC fractions. Large estuary intertidal zones were characterized by variable sedimentary OC content and carbon stock due to variable clay contents, and by higher terrestrial OC fractions due to higher riverine input. Non-estuarine intertidal zones were characterized by lower sedimentary $\mathrm{OC}$ content and carbon stock due to higher dynamic sorting of sediments, and by lower terrestrial $\mathrm{OC}$ fractions due to the lack of riverine input. Carbon stocks in intertidal sediments from China's coastal area were comparable with those in shelf sediments. More comprehensive comparisons of sedimentary OC properties in individual intertidal zone are required in future studies to understand the variability of $\mathrm{OC}$ in intertidal sediments.

\section{Declaration of Competing Interest}

The authors declare that they have no known competing financial interests or personal relationships that could have appeared to influence the work reported in this paper.

\section{Acknowledgments}

We are grateful to $\mathrm{Li} \mathrm{Li}$ and Hailong Zhang for technical support. This work was supported by the National Natural Science Foundation of China (U1706219, 41630966, 41520104009). This is MCTL (Key Laboratory of Marine Chemistry Theory and Technology) con- tribution \#199. We thank two anonymous reviewers for numerous constructive suggestions for improving the manuscript.

\section{Appendix A. Supplementary material}

Supplementary data to this article can be found online at https://doi.org/10.1016/j.orggeochem.2020.103993.

\section{Associate Editor-Marcus Elvert}

\section{References}

Abballe, P.A., Chivas, A.R., 2017. Organic matter sources, transport, degradation and preservation on a narrow rifted continental margin: Shoalhaven, southeast Australia. Organic Geochemistry 112, 75-92.

Avelar, S., van der Voort, T.S., Eglinton, T.I., 2017. Relevance of carbon stocks of marine sediments for national greenhouse gas inventories of maritime nations. Carbon Balance and Management 12, 10.

Bi, R., Chen, X., Zhang, J., Ishizaka, J., Zhuang, Y.P., Jin, H.Y., Zhang, H.L., Zhao, M.X., 2018. Water mass control on phytoplankton spatiotemporal variations in the northeastern East China Sea and the western Tsushima Strait revealed by lipid biomarkers. Journal of Geophysical Research: Biogeosciences 123, 1318-1332.

Bianchi, T.S., Cui, X., Blair, N.E., Burdige, D.J., Eglinton, T.I., Galy, V., 2018. Centers of organic carbon burial and oxidation at the land-ocean interface. Organic Geochemistry 115, 138-155.

Breen, N.A., Orange, D.L., 1992. The effects of fluid escape on accretionary wedges 1. Variable porosity and wedge convexity. Journal of Geophysical Research Solid Earth 97, 9265-9275.

Burdige, D.J., 2005. Burial of terrestrial organic matter in marine sediments: A reassessment. Global Biogeochemical Cycles 19, GB4011.

Chen, X.Y., Liu, J.Q., Guo, L., Liu, X.L., Yin, P., 2016. Short term depositional dynamics processing at Dagu River mouth of Jiaozhou Bay. Marine Geology \& Quaternary Geology 6, 45-50 (in Chinese with an English abstract).

Cividanes, S., Incera, M., López, J., 2002. Temporal variability in the biochemical composition of sedimentary organic matter in an intertidal flat of the Galician coast (NW Spain). Oceanologica Acta 25, 1-12.

Cook, P.L.M., Revill, A.T., Clementson, L.A., Volkman, J.K., 2004. Carbon and nitrogen cycling on intertidal mudflats in a temperate Australian estuary. III. Sources of organic matter. Marine Ecology Progress Series 280, 55-72.

Dagg, M., Benner, R., Lohrenz, S., Lawrence, D., 2004. Transformation of dissolved and particulate materials on continental shelves influenced by large rivers: plume processes. Continental Shelf Research 24, 833-858.

Dai, Q.Y., Zou, L., Peng, Y., 2017. Distribution and degradation of lignin in the sediment of intertidal mudflat of Yellow River estuary. Marine Environmental Science 36, 209-215 (in Chinese with an English abstract).

Díez-Minguito, M., Contreras, E., Polo, M.J. Losada, M.A., 2013, Spatio-temporal distribution, along-channel transport, and post-riverflood recovery of salinity in the Guadalquivir estuary (SW Spain). Journal of Geophysical Research, Oceans 118, 2267-2278.

Diesing, M., Kröger, S., Parker, R., Jenkins, C., Mason, C., Weston, K., 2017. Predicting the standing stock of organic carbon in surface sediments of the North-West European continental shelf. Biogeochemistry 135, 183-200.

Dong, L., Su, J., Li, Y. Xia, X., Guan, W., 2006. Physical processes and sediment dynamics in the Pearl River. In: The Environment in Asia Pacific Harbors. Springer, Dordrecht, pp. 127-137.

Eglinton, T.I., Eglinton, G., 2008. Molecular proxies for paleoclimatology. Earth and Planetary Science Letters 275, 1-16.

Freese, E., Köster, J., Rullkötter, J., 2008. Origin and composition of organic matter in tidal flat sediments from the German Wadden Sea. Organic Geochemistry 39 $820-829$.

Fulton, E.A., Smith, A.D.M., Johnson, C.R., 2004. Biogeochemical marine ecosystem models I: IGBEM-a model of marine bay ecosystems. Ecological Modelling 174 267-307.

Gaiser, E.E., Johansen, J., 2000. Freshwater diatoms from Carolina bays and other isolated wetlands on the Atlantic coastal plain of South Carolina, U.S.A. with descriptions of seven taxa new to science. Diatom Research 15, 75-130.

Gao, X.L., Chen, S.Y., 2008. Petroleum pollution in surface sediments of Daya Bay, South China, revealed by chemical fingerprinting of aliphatic and alicyclic hydrocarbons. Estuarine, Coastal and Shelf Science 80, 95-102.

Gonzalez-Macias, C., Schifter, I., Lluch-Cota, D.B., Mendez-Rodriguez, L., HernandezVazquez, S., 2006. Distribution, enrichment and accumulation of heavy metals in coastal sediments of Salina Cruz Bay, Mexico. Environmental Monitoring and Assessment 118, 211-230.

Halpern, B.S., Longo, C. Hardy, D., McLeod, K.L., Samhouri, J.F. Katona, S.K., Kleisner, K., Lester, S.E., O’Leary, J., Ranelletti, M., Rosenberg, A.A., Scarborough, C., Selig, E. R., Best, B.D., Brumbaugh, D.R., Chapin, F.S., Crowder, L.B., Daly, K.L., Doney, S.C. Elfes, C., Fogarty, M.J., Gaines, S.D., Jacobsen, K.I., Karrer, L.B., Leslie, H.M., Neeley, E., Pauly, D., Polasky, S., Ris, B., St Martin, K., Stone, G.S., Sumaila, U.R. Zeller, D., 2012. An index to assess the health and benefits of the global ocean. Nature 488, 615-620. 
Hensen, C., Zabel, M., Schulz, H.D., 2000. A comparison of benthic nutrient fluxes from deep-sea sediments off Namibia and Argentina. Deep Sea Research Part II: Topical Studies in Oceanography 47, 2029-2050.

Hopmans, E.C., Weijers, J.W.H., Schefuss, E., Herfort, L., Sinninghe Damsté, J.S. Schouten, S., 2004. A novel proxy for terrestrial organic matter in sediments based on branched and isoprenoid tetraether lipids. Earth and Planetary Science Letters 224, 107-116.

Hu, B.Q., Li, G.G., Li, J., Yang, M., Wang, L.B., Bu, R.Y., 2011. Spatial variability of the ${ }^{210} \mathrm{~Pb}$ sedimentation rates in the Bohai and Huanghai Seas and its influencing factors. Acta Oceanologica Sinica 33, 125-133 (in Chinese with an English abstract).

Hu, L.M., Guo, Z.G., Feng, J.L., Yang, Z.S., Fang, M., 2009. Distributions and sources of bulk organic matter and aliphatic hydrocarbons in surface sediments of the Bohai Sea, China. Marine Chemistry 113, 197-211.

Hu, L.M., Shi, X.F., Yu, Z.G., Lin, T., Wang, H.J., Ma, D.Y., Guo, Z.G., Yang, Z.S., 2012. Distribution of sedimentary organic matter in estuarine-inner shelf regions of the East China Sea: implications for hydrodynamic forces and anthropogenic impact. Marine Chemistry 142, 29-40.

Hu, Q., Qu, L., Huang, B.G., Li, Q., You, Q.M., 2016. Status and evaluation on nutrients for the adjacent sea water of the Yellow River estuary in autumn of 2014 Marine Environmental Science 35, 732-738.

Huguet, C., Hopmans, E.C., Febo-Ayala, W., Thompson, D.H., Sinninghe Damsté, J.S., Schouten, S., 2006. An improved method to determine the absolute abundance of glycerol dibiphytanyl glycerol tetraether lipids. Organic Geochemistry 37, 1036-1041.

Hung, C.C., Gong, G.C., 2011. Biogeochemical responses in the southern East China Sea after typhoons. Oceanography 24, 42-51.

Jiang, Z., Liu, J., Chen, J., Chen, Q., Yan, X., Xuan, J., Zeng, J., 2014. Responses of summer phytoplankton community to drastic environmental changes in the Changjiang (Yangtze River) estuary during the past 50 years. Water Research $54,1-11$.

Ke, X., Evans, G., Collins, M.B., 1996. Hydrodynamics and sediment dynamics of The Wash embayment, eastern England. Sedimentology 43, 157-174.

Killops, S., Killops, V., 2005. Chemical stratigraphic concepts and tools. In: Introduction to Organic Geochemistry, second ed., pp. 166-245.

Kim, J.H., Schouten, S., Buscail, R., Ludwig, W., Bonnin, J., Sinninghe Damsté, J.S. Bourrin, F. 2006. Origin and distribution of terrestrial OM in the NW Mediterranean (Gulf of Lions): Exploring the newly developed BIT index. Geochemistry, Geophysics, Geosystems 7, Q11017.

Leininger, S., Urich, T., Schloter, M., Schwark, L., Qi, J., Nicol, G.W., Prosser, J.I., Schuster, S.C., Schleper, C., 2006. Archaea predominate among ammoniaoxidizing prokaryotes in soils. Nature 442, 806-809.

Li, R.X., Wang, Y., Kang, J.H., Chen, X.Q., 2011. Temporal and spatial variations of chlorophyll a concentration and primary production in Jiulongjiang estuary waters. Journal of Oceanography in Taiwan Strait 84, 383-402.

Lin, T., Ye, S., Ma, C., Ding, X., Brix, H., Yuan, H., Guo, Z., 2013. Sources and preservation of organic matter in soils of the wetlands in the Liaohe (Liao River) Delta, North China. Marine Pollution Bulletin 71, 276-285.

Liu, D.Y., Li, X., Emeis, K.C., Wang, Y.J., Richard, P., 2015. Distribution and sources of organic matter in surface sediments of Bohai Sea near the Yellow River Estuary, China, Estuarine, Coastal and Shelf Science. 165, 128-136.

Liu, D.Y., Han, Q.Y., 2016. The Investigation Method and Practice of Intertidal Zone, Beijing (in Chinese).

Liu, J.E., Zhou, H.X., Oin, P., Zhou, J., 2007. Effects of Spartina alterniflora salt marshes on organic carbon acquisition in intertidal zones of Jiangsu Province, China. Ecological Engineering 30, 240-249.

Liu, M., Hou, L.J., Xu, S.Y., Ou, D.N., Yang, Y., Yu, J., Wang, Q., 2006. Organic carbon and nitrogen stable isotopes in the tidal sediments from the Yangtze Estuary, China. Marine Pollution Bulletin 52, 1625-1633.

Liu, X., Yu, Z., Song, X., Cao, X., 2009. The nitrogen isotopic composition of dissolved nitrate in the Yangtze river (Changjiang) estuary, China. Estuarine, Coastal and Shelf Science 85, 641-650.

Lopes dos Santos, R.A., Vane, C.H., 2019. Tracking natural organic carbon in the River Clyde, UK, using glycerol dialkyl glycerol tetraethers. Earth and Environmental Science Transactions of the Royal Society of Edinburgh 108, 289-298.

Malvarez, G.C., Cooper, J.A.G., Jackson, D.W.T., 2001. Relationships between waveinduced currents and sediment grain size on a sandy tidal-flat. Journal of Sedimentary Research 71, 705-712.

Marchand, C., Lallier-Verges, E., Baltzer, F., 2003. The composition of sedimentary $\mathrm{OM}$ in relation to the dynamic features of a mangrove-fringed coast in French Guiana. Estuarine, Coastal and Shelf Science 56, 119-130.

Middelburg, J.J., Herman, P.M.J., 2007. Organic matter processing in tidal estuaries. Marine Chemistry 106, 127-147.

Middelburg, J.J., Soetaert, K., Herman, P.M.J., 1997. Empirical relationships for use in global diagenetic models. Deep Sea Research 44, 327-344.

Nellemann, C., Corcoran, E., Duarte, C.M., Valdés, L., Young, C.D., Fonseca, L., Grimsditch, G., 2009. Blue Carbon: The Role of Healthy Oceans in Binding Carbon: A Rapid Response Assessment. United Nations Environmental Programme/Earthprint.

Nie, J.Q., 2018. Distribution and Sources of Sedimentary Organic Matters in Typical Intertidal Zone, Eastern China Masters thesis. East China Normal University.

Pancost, R.D., Boot, C.S., 2004. The palaeoclimatic utility of terrestrial biomarkers in marine sediments. Marine Chemistry 92, 239-261.

Park, J., Kwon, B.O., Kim, M., Hong, S., Ryu, J., Song, S.J., Khim, J.S., 2014 Microphytobenthos of Korean tidal flats: A review and analysis on flora distribution and tidal dynamics. Ocean and Coastal Management 102, 471-482.
Peeters, F., Straile, D., Lorke, A., Livingstone, D.M., 2010. Earlier onset of the spring phytoplankton bloom in lakes of the temperate zone in a warmer climate. Global Change Biology 13, 1898-1909.

Pinckney, J.L., Paerl, H.W., Harrington, M.B., Howe, K.E., 1998. Annual cycles of phytoplankton community-structure and bloom dynamics in the Neuse River Estuary, North Carolina. Marine Biology 131, 371-381.

Pote, J., Haller, L., Loizeau, J.L., Bravo, A.G., Sastre, V., Wildi, W., 2008. Effects of a sewage treatment plant outlet pipe extension on the distribution of contaminants in the sediments of the Bay of Vidy, Lake Geneva, Switzerland. Bioresource Technology 99, 7122-7131.

Powers, L.A., Werne, J.P., Johnson, T.C., Hopmans, E.C., Sinninghe Damsté, J.S., Schouten, S., 2004. Crenarchaeotal membrane lipids in lake sediments: A new paleotemperature proxy for continental paleoclimate reconstruction? Geology 32, 613-616.

Powers, L.A., Werne, J.P., Vanderwoude, A.J., Sinninghe Damsté, J.S., Hopmans, E.C., Schouten, S., 2010. Applicability and calibration of the TEX ${ }_{86}$ paleothermometer in lakes. Organic Geochemistry 41, 404-413.

Qiao, S., Yang, Z., Pan, Y., Guo, Z., 2007. Metals in suspended sediments from the Changjiang (Yangtze River) and Huanghe (Yellow River) to the sea, and their comparison. Estuarine, Coastal and Shelf Science 74, 539-548.

Reise, K., 1985. Tidal Flat Ecology. Springer, Berlin Heidelberg, pp. 1-183.

Rochelle-Newall, E.J., Chu, V.T., Pringault, O., Amouroux, D., Arfi, R., Bettarel, Y., Bouvier, T., Bouvier, P., Got, P., Nguyen, T.M.H., Mari, X., Navarro, P., Duong, T.N., Cao, T.T.T., Pham, T.T., Ouillon, S., Torréton, J.P., 2011. Phytoplankton distribution and productivity in a highly turbid, tropical coastal system (Bach Dang Estuary, Vietnam). Marine Pollution Bulletin 62, 2317-2329.

Schouten, S., Hopmans, E.C., Pancost, R.D., Sinninghe Damsté, J.S., 2000. Widespread occurrence of structurally diverse tetraether membrane lipids: Evidence for the ubiquitous presence of low-temperature relatives of hyperthermophiles. Proceedings of the National Academy of Sciences USA 97, $14421-14426$

Schouten, S., Huguet, C., Hopmans, E.C., Kienhuis, M.V., Sinninghe Damsté, J.S., 2007. Analytical methodology for $\mathrm{TEX}_{86}$ paleothermometry by high-performance liquid chromatography/atmospheric pressure chemical ionization-mass spectrometry. Analytical Chemistry 79, 2940-2944.

Shiah, F.K., Chung, S.W., Kao, S.J., Gong, G.C., Liu, K.K., 2000. Biological and hydrographical responses to tropical cyclones (typhoons) in the continental shelf of the Taiwan Strait. Continental Shelf Research 20, 2029-2044.

Sinninghe Damsté, J.S., Schouten, S., Hopmans, E.C., van Duin, A.C.T., Geenevasen, J. A.J., 2002. Crenarchaeol: the characteristic core glycerol dibiphytanyl glycerol tetraether membrane lipid of cosmopolitan pelagic crenarchaeota. Journal of Lipid Research 43, 1641-1651.

Smith, R.W., Bianchi, T.S., Li, X., 2012. A re-evaluation of the use of branched GDGTs as terrestrial biomarkers: Implications for the BIT Index. Geochimica et Cosmochimica Acta 80, 14-29.

Uncles, R.J., Lewis, R.E., 2001. The transport of fresh water from river to coastal zone through a temperate estuary. Journal of Sea Research 46, 161-175.

Venkatramanan, S., Chung, S.Y., Ramkumar, T., Park, N., 2014. Grain size trend and hydrodynamic condition of Tirumalairajan River estuary, east coast of India. Oceanology 544, 532-540.

Volkman, J.K., 2003. Sterols in microorganisms. Applied Microbiology and Biotechnology 60, 495-506.

Volkman, J.K., 2006. Lipid markers for marine organic matter. In: Volkman, J.K. (Ed.), Marine Organic Matter: Biomarkers, Isotopes and DNA. Springer, Berlin Heidelberg.

Volkman, J.K., Barrett, S.M., Blackburn, S.I., Mansour, M.P., Sikes, E.L., Gelin, F., 1998. Microalgal biomarkers: a review of recent research developments. Organic Geochemistry 29, 1163-1179.

Volkman, J.K., Rohjans, D., Rullkötter, J., Scholz-Böttcher, B.M., Liebezeit, G., 2000. Sources and diagenesis of organic matter in tidal flat sediments from the German Wadden Sea. Continental Shelf Research 20, 1139-1158.

Wang, E.H., 2017. Nitrogen Pollution in the Surface Sediments and Communities of Bacterioplankton Response to Nitrogen Pollution among Different Intertidal Zones Masters thesis. Yantai Institute of Coastal Zone Research, Chinese Academy of Sciences.

Wang, K., Chen, J., Jin, H., Li, H., Gao, S., Xu, J., Weng, H., 2014. Summer nutrient dynamics and biological carbon uptake rate in the Changjiang River plume inferred using a three end-member mixing model. Continental Shelf Research 91, 192-200.

Wang, X.C., Chen, R.F., Berry, A., 2003. Sources and preservation of OM in Plum Island salt marsh sediments (MA, USA): long-chain $n$-alkanes and stable carbon isotope compositions. Estuarine, Coastal and Shelf Science 58, 917-928.

Wang, X.H., Wang, H.J., 2010. Tidal straining effect on the suspended sediment transport in the Huanghe (Yellow River) Estuary, China. Ocean Dynamics 60, $1273-1283$

Weijers, J.W., Schouten, S., van der Linden, M., van Geel, B., Sinninghe Damsté, J.S., 2004. Water table related variations in the abundance of intact archaeal membrane lipids in a Swedish peat bog. FEMS Microbiology Letters 239, 51-56.

Weijers, J.W., Schouten, S. Hopmans, E.C., Geenevasen, J.A., David, O.R., Coleman, J. M., Sinninghe Damsté, J.S., 2006a. Membrane lipids of mesophilic anaerobic bacteria thriving in peats have typical archaeal traits. Environmental Microbiology 8, 648-657.

Weijers, J.W.H., Schouten, S., Spaargaren, O.C., Sinninghe Damsté, J.S., 2006b. Occurrence and distribution of tetraether membrane lipids in soils: Implications for the use of the $\mathrm{TEX}_{86}$ proxy and the BIT index. Organic Geochemistry 37, 1680-1693. 
Weijers, J.W., Schouten, S., van den Donker, J.C., Hopmans, E.C., Sinninghe Damsté, J. S. 2007. Environmental controls on bacterial tetraether membrane lipid distribution in soils. Geochimica et Cosmochimica Acta 71, 703-713.

Weijers, J.W.H., Schouten, S., Schefuss, E., Schneider, R.R., Sinninghe Damsté, J.S., 2009. Disentangling marine, soil and plant organic carbon contributions to continental margin sediments: A multi-proxy approach in a 20,000-year sediment record from the Congo deep-sea fan. Geochimica et Cosmochimica Acta $73,119-132$.

Witt, M.L.I., Mather, T.A., Baker, A.R., De Hoog, J.C.M., Pyle, D.M., 2010. Atmospheric trace metals over the south-west Indian Ocean: Total gaseous mercury, aerosol trace metal concentrations and lead isotope ratios. Marine Chemistry 121, 2-16.

Wu, W., Meador, T., Hinrichs, K.U., 2018. Production and turnover of microbial organic matter in surface intertidal sediments. Organic Geochemistry 121, 104113.

Xia, B., Zhang, L., 2011. Carbon distribution and fluxes of 16 rivers discharging into the Bohai Sea in summer. Acta Oceanologica Sinica 30, 43-54.

Xing, L., Zhang, H., Yuan, Z., Sun, Y., Zhao, M., 2011. Terrestrial and marine biomarker estimates of OM sources and distributions in surface sediments from the East China Sea shelf. Continental Shelf Research 31, 1106-1115.

Xu, D., Chu, F.Y., Yang, H.L., Chen, L., Li, T.J., 2012. Modern sedimentation rates in the Beibu Gulf. Mar. Geol. Quat. Geol. 32, 17-26 (in Chinese with an English abstract).

Xu, X., Yu, Z.M., He, L.Y., Cheng, F.J., Cao, X.H., Song, X.X., 2017. Nano- and micro phytoplankton community characteristics in brown tide bloom-prone waters of the Qinhuangdao coast, Bohai sea, China. Science China Earth Sciences 60, 1-12.

Yang, H.F., Yang, S.L., Xu, K.H., 2017. River-sea transitions of sediment dynamics: A case study of the tide-impacted Yangtze River estuary. Estuarine, Coastal and Shelf Science 196, 207-216.

Yang, S.L., Li, H., Ysebaert, T., Bouma, T.J., Zhang, W.X., Wang, Y.Y., Li, P., Li, M., Ding, P.X., 2008. Spatial and temporal variations in sediment grain size in tidal wetlands, Yangtze Delta: On the role of physical and biotic controls. Estuarine, Coastal and Shelf Science 77, 657-671.
Yu, F.L., Zong, Y.Q., Lloyd, J.M., Huang, G.Q., Leng, M.J., Kendrick, C., Lamb, A.L., Yim, W.W.S., 2010. Bulk organic $\delta^{13} \mathrm{C}$ and $\mathrm{C} / \mathrm{N}$ as indicators for sediment sources in the Pearl River delta and estuary, southern China. Estuarine, Coastal and Shelf Science 87, 618-630.

Yuan, H.W., Chen, J.F, Ye, Y, Lou, Z.H. Jin, A.M., Chen, X.G. Jiang Z.P. Lin, Y.S. Arthur Chen, C.T., Loh, P.S., 2017. Sources and distribution of sedimentary organic matter along the Andong salt marsh, Hangzhou Bay. Journal of Marine Systems 174, 78-88.

Yu, H., Yu, Z., Song, X., Cao, X., Yuan, Y., Lu, G., 2015. Seasonal variations in the nitrogen isotopic composition of dissolved nitrate in the Changjiang river estuary, china. Estuarine, Coastal and Shelf Science 155, 148-155.

Yu, Q, Wang, Y., Gao, S., Flemming B. 2012. Modeling the formation of a sand bar within a large funnel-shaped, tide-dominated estuary: Qiantangjiang Estuary, China. Marine Geology 299-302, 63-76.

Zaghden, H., Kallel, M., Elleuch, B., Oudot, J., Saliot, A., 2007. Sources and distribution of aliphatic and polyaromatic hydrocarbons in sediments of Sfax, Tunisia, Mediterranean Sea. Marine Chemistry 105, 70-89.

Zhang, J.M., Liu, S., Zhang, Q., Li, Q.L., 2010. Population variation of phytoplankton around Yellow River estuary. Marine Environmental Science 29, 834-837.

Zhang, W.Y., Jin, H.Y., Zhang, F.Y., Zhao, G.J., Yang, K.H., Li, H.L., Bai, Y.C., Gao, W.L. 2009. Organic carbon distribution in the Yangtze River Estuary-Hangzhou Bay and its adjacent sea area. Advances in Earth Science 11, 1202-1208.

Zhao, M.X., Mercer, J.L., Eglinton, G., Higginson, M.J., Huang, C.Y., 2006. Comparative molecular biomarker assessment of phytoplankton paleo productivity for the last 160 kyr off Cap Blanc, NW Africa. Organic Geochemistry 37, 72-97.

Zhou, M.J. Shen, Z.L. Yu, R.C. 2008, Responses of a coastal phytoplankton community to increased nutrient input from the Changjiang (Yangtze) River. Continental Shelf Research 28, 1483-1489.

Zhu, C., Wang, Z.H., Xue, B., Yu, P.S., Pan, J.M., Wagner, T., Pancost, R.D., 2011. Characterizing the depositional settings for sedimentary organic matter distributions in the Lower Yangtze River-East China Sea Shelf System. Estuarine, Coastal and Shelf Science 93, 182-191. 